Article

\title{
Studies for Improving a Rat Model of Alzheimer's Disease: Icv Administration of Well-Characterized $\beta$-Amyloid 1-42 Oligomers Induce Dysfunction in Spatial Memory
}

\author{
Ágnes Kasza ${ }^{1}$, Botond Penke ${ }^{1, *}$, Zsuzsanna Frank ${ }^{1}$, Zsolt Bozsó ${ }^{1}$, Viktor Szegedi ${ }^{1}$ (iD, \\ Ákos Hunya ${ }^{2}$, Klaudia Németh ${ }^{1}$, Gábor Kozma ${ }^{3}$ and Lívia Fülöp ${ }^{1}$ \\ 1 Department of Medical Chemistry, University of Szeged, Dome square 8, Szeged H-6720, Hungary; \\ kaszagi@gmail.com (Á.K.); frankzsu@gmail.com (Z.F.); bozso.zsolt@med.u-szeged.hu (Z.B.); \\ szegv@yahoo.com (V.S.); klausz20@gmail.com (K.N.); fulop.livia@med.u-szeged.hu (L.F.) \\ 2 LipidArt Research and Development Ltd., Temesvári krt. 62, Szeged H-6726, Hungary; \\ akos.hunya@lipidart.com \\ 3 Department of Applied and Environmental Chemistry, University of Szeged, Rerrich Béla square 1, \\ Szeged H-6720, Hungary; kozmag@chem.u-szeged.hu \\ * Correspondence: penke.botond@med.u-szeged.hu; Tel.: +36-62-545-135
}

Received: 9 October 2017; Accepted: 13 November 2017; Published: 18 November 2017

\begin{abstract}
During the past 15 years, several genetically altered mouse models of human Alzheimer's disease (AD) have been developed. These costly models have greatly facilitated the evaluation of novel therapeutic approaches. Injecting synthetic $\beta$-amyloid $(A \beta)$ 1-42 species into different parts of the brain of non-transgenic rodents frequently provided unreliable results, owing to a lack of a genuine characterization of the administered $A \beta$ aggregates. Previously, we have published a new rat AD-model in which protofibrillar-fibrillar A $\beta 1-42$ was administered into rat entorhinal cortex (Sipos 2007). In order to develop a more reliable model, we have injected well-characterized toxic soluble A $\beta 1-42$ species (oligomers, protofibrils and fibrils) intracerebroventricularly (icv) into rat brain. Studies of the distribution of fluorescent-labeled $A \beta 1-42$ in the brain showed that soluble $A \beta$-species diffused into all parts of the rat brain. After seven days, the $A \beta$-treated animals showed a significant decrease of spatial memory in Morris water maze test and impairment of synaptic plasticity (LTP) measured in acute hippocampal slices. The results of histological studies (decreased number of viable neurons, increased tau levels and decreased number of dendritic spines) also supported that icv administration of well-characterized toxic soluble $A \beta$ species into rat brain provides a reliable rat AD-model.
\end{abstract}

Keywords: amyloid beta; AD rat model; icv administration; hippocampus; spatial memory; Morris water maze; long-term potentiation; Golgi staining

\section{Introduction}

Alzheimer's disease (AD) is the most common form of dementia. AD is a neurodegenerative disease that begins with synaptic dysfunction, which results in the loss of dendritic spines and post-synaptic density, finally leading to the failure of neuronal networks [1]. The initial abnormal neuronal activity progressively triggers neuronal cell death [2] as a consequence of the disruption of many intracellular processes (e.g., protein folding and degradation, mitochondrial function, etc.) [3]. $\beta$-amyloid $(A \beta)$ may play a crucial role in the initiation of AD.

AD demonstrates phenotypic (clinical, imaging and pathological) heterogeneity [4]. Plenty of hypotheses try to explain the etiopathology of the disease. Based on the time of onset, AD is classified 
into two types [5]. Early-onset AD (EOAD) typically develops before the age of 65 years. The other form, late-onset $\mathrm{AD}$ (LOAD), develops in patients older than 65 years. The production and clearance of $A \beta$ is regulated by a large group of genes. The genetic background of $A D$ is widely reviewed [6-9]. For references, see also http:/ /www.molgen.ua.ac.be/admutations/.

From the different $\mathrm{AD}$ theories, only the $\mathrm{A} \beta$ hypothesis has survived the conflicting results of $\mathrm{AD}$ research. The original hypothesis states that accumulation of $A \beta$ in the brain is the primary event that drives $A D$ pathogenesis $[10,11]$. The $A \beta$ protein (a heterogeneous mixture of peptides of 39-43 AA) is derived from the proteolytic cleavage of amyloid precursor protein (APP) by $\beta$ - and y-secretases. $\mathrm{A} \beta$ accumulates in the brain mainly as extracellular plaques, but accumulation of intracellular $A \beta$ also occurs in the early stage of $\mathrm{AD}[12,13]$.

According to Walsh, soluble oligomers and protofibrils initiate AD pathomechanism [14]. Other results emphasize the important role of $A \beta$ oligomers, protofibrils and fibrils in $A \beta$ toxicity [15]. Recently, the formation of soluble toxic oligomers is considered to be a key event in AD pathogenesis. Increasing evidence indicates that the low-molecular weight oligomeric pre-fibrillar aggregates are the most highly cytotoxic species [16]. The precise molecular mechanisms of AD are still not fully understood despite 30 years of very intensive research. It is clear that LOAD is a multifactoral disease with a complex genetic background.

The familial type EOAD has simple genetics: one of the three main AD proteins (the amyloid precursor protein (APP), presenilin-1 and -2 (PSEN1 and PSEN2)) have mutations. Protein dyshomeostasis and amyloid formation are central events of both forms of $\mathrm{AD}$, neuroinflammation and vascular dysfunction may play crucial roles in the onset of LOAD.

There is no "natural" animal model of the disease due to a poor understanding of AD and the complexity of the human brain [17]. Pharmacological and genetic AD- models and different animal species (primates, dogs, rodents, etc.) have been used in AD experiments during the 25 last years $[18,19]$. Genetically modified (transgenic, knock-in and knock-out) animal AD models provide a powerful approach to understand AD pathogenesis and study the disease [20]. These models allow investigation of the early stages of the disorder. There are several Caenorhabditis elegans [21,22] and Drosophila melanogaster [23,24] models of AD [20], which are widely used in screening experiments. A great variety of first- and second-generation transgenic mouse models of AD have been developed during the last 20 years for studying the pathophysiological processes of the disease, as reviewed in [25-31]. The transgenic mouse and knockout models analyze certain aspects of AD pathology, allowing exploration of unknown territories and revealing new pathogenic possibilities [32]. Summaries of the most prominent mouse models of AD have been published very recently [31,33,34]. Transgenic rat models were also introduced [35,36], possessing the key histopathological features of human AD (amyloid plaques, neurofibrillary tangles) without widespread cell loss. However, they have had limited success in translation of these findings into the clinics. The most obvious divergence of transgenic animal models from human $\mathrm{AD}$ is the artificial nature of transgenic technology. Rodents do not develop AD. The normal in vivo concentration of $\mathrm{A} \beta$ might be in picomolar range, contrary to that in human $A D$ brains that has nanomolar $A \beta$ levels. In addition, rodent $A \beta$ differs from human $A \beta$ by 3 AA substitutions (R5G, Y10F and H13R) and these changes also might prevent amyloid aggregation. As a consequence, the introduction of at least one of the main human AD genes (APP, PS1, PS2 and ApoE) is mandatory to model the pathology in rodents [33]. The ideal transgenic model should mimic multiple aspects of the disease including its etiology and a time-dependent progression of the pathology, which involves similar structures and cells, alike in human pathology.

Other less expensive, pharmacological animal models have also been introduced during the last 20 years. $\mathrm{AD}$ is considered to be a synaptic failure [37] and $\mathrm{A} \beta$ oligomers induce synaptic dysfunction $[38,39]$, thus $A \beta$ peptides have been used in model experiments. Synthetic A $\beta$-oligomers impaired long-term memory after icv injection into mice [40-44]. (A $\beta$ peptides after icv injections reach brain cells by CSF (cerebrospinal fluid) influx via the perivascular and glymphatic pathways [45]). Rats offer numerous advantages over mice for developing AD models. Rats are closer to humans than 
mice [46]. Larger body and brain size facilitates in vivo electrophysiology, neurosurgical procedures and neuroimaging. The resurgence of interest in the rat as the animal model of AD led to the use of different types of rat models [19]. A $\beta$ peptides were also administered intrahippocampally into rat brains [47-50]. Intracerebroventricular injection of $A \beta 1-42$ to rats and mice were used to model $\mathrm{AD}[51,52]$. Intranasal delivery or microinjecting $\mathrm{A} \beta$ oligomers into the entorhinal cortex was also applied in rats $[53,54]$. Two recent articles have compared the different pharmacological and genetic models of AD used in drug discovery [55,56].

The crucial problem of the application of $A \beta$ in rat models is the heterogeneity of the peptide samples [57]. $A \beta$ exists in vitro and in vivo as a continuum of different oligomeric states, none of which are particularly stable. All forms of $A \beta$-derived oligomers are potentially neurotoxic. During the fibril formation, several coexisting species are formed, giving rise to a highly heterogeneous mixture. The most difficult problem of the use of $A \beta 1-42$ microinjections is the structural heterogeneity of oligomeric samples. This heterogeneity may cause severe problems in the evaluation of the results of $\mathrm{A} \beta$-injection animal models and reproduction of in vivo experiments.

In our laboratory, we have tried to work out a novel, robust AD rat model, using icv administration of oligomeric $A \beta 1-42$. The aim of the present study was to develop a reliable and cheap method by administering well-characterized $A \beta$ peptides into the brain of wild-type rats. Atomic force microscopy was used for the characterization of $A \beta$ oligomers. We have used histochemical methods to track the distribution of fluorescently labeled $A \beta$ and characterize various neurodegenerative markers (number of viable neurons and dendritic spines, levels of tau). We also show that oligomeric $A \beta$-treated rats exhibit impaired synaptic plasticity (decreased LTP level) and cognitive disturbances (memory and learning behavior changes).

\section{Results}

\subsection{Pilot Experiment with Icv Administration of AMCA-Labeled A $\beta 1-42$ Oligomers}

Before the icv administration experiments, we wanted to see whether $A \beta 1-42$ oligomers could penetrate across the cerebroventricular wall. We have shown that the diffusion of the fibrilar form of A $\beta 1-42$ is stopped by the ventricular wall, thus, an icv injection would be useless (Figure 1). Therefore our first aim was to demonstrate that oligomeric form of A $\beta 1-42$ can reach the hippocampal (HC) region after icv injection. Using an unilateral injection of AMCA-labeled oligomeric A $\beta 1-42$ (oA $\beta 1-42)$ into the right lateral ventricle, we have found that the $A \beta 1-42$ oligomers appear in the brain parenchyma: we could detect a few of fluorescent signs in the HC area as early as 5 min after injection (Figure 2A,B). The number of signs, namely of $A \beta 1-42$ oligomers, was evidently higher around the HC area 60 min after the injection (Figure $2 \mathrm{C}$ ), proving that the AMCA-labeled A $\beta 1-42$ penetrates across the ependyma, or penetrates into the brain by the glymphatic flow [58].
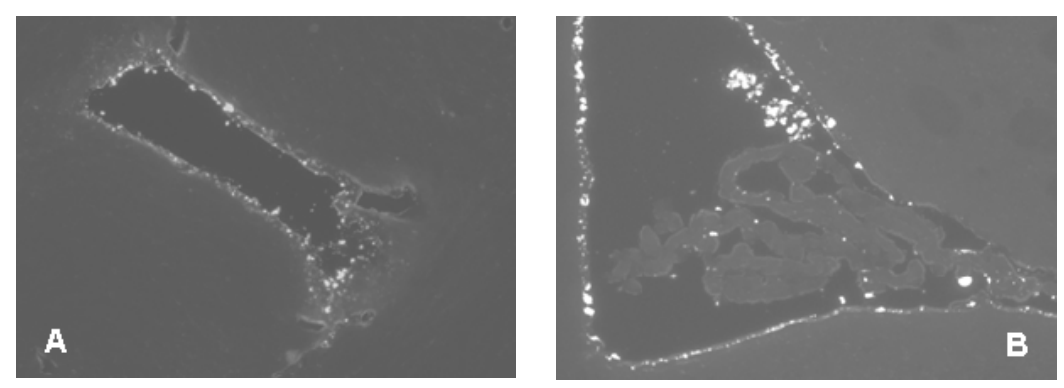

Figure 1. In this figure, icv administered fibrillar $A \beta 1-42$ does not penetrate the ependyma and remains in the ventricles. Two representative examples of brain sections $(\mathbf{A}, \mathbf{B})$ after icv injected AMCA-labelled $A \beta 1-42$ fibrils show the presence of the peptide in the ventricles at $1 \mathrm{~h}$ after injection. Animals were injected bilaterally with $10-10 \mu \mathrm{L}$ solution of AMCA fA $\beta 1-42$, and the surgical procedure was the same as described in Materials and Methods. 


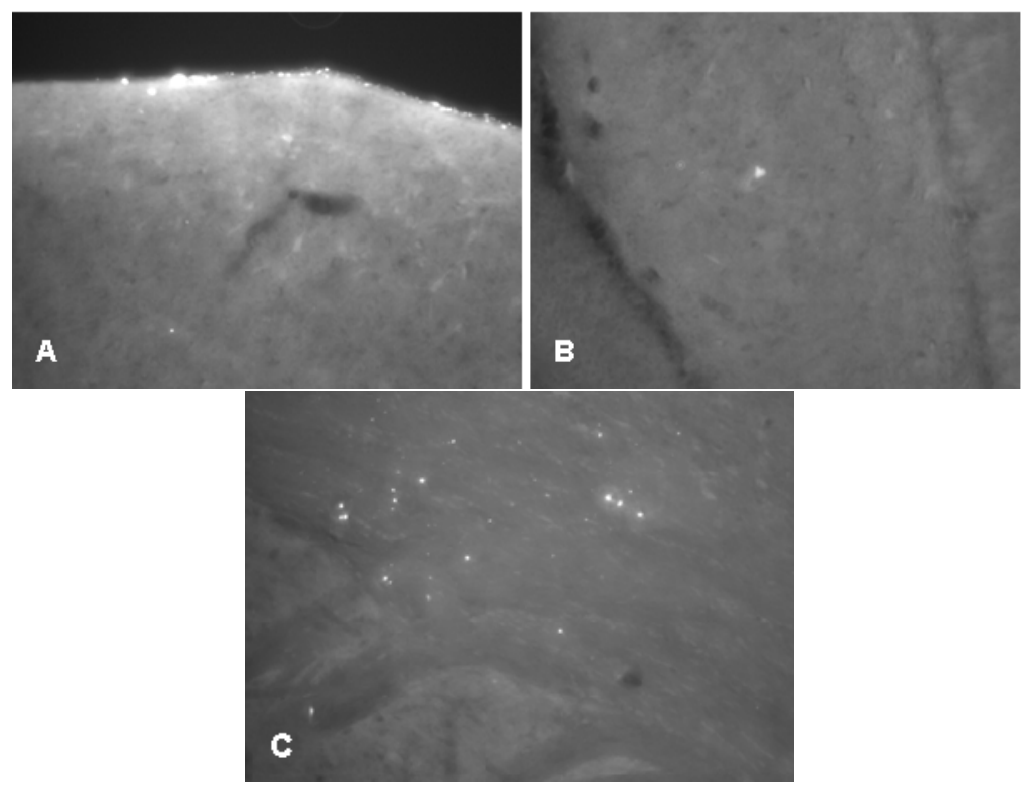

Figure 2. Oligomeric A $\beta 1-42$ enters the brain parenchyma. Representative examples of brain sections after icv injected AMCA-labelled A $\beta 1-42$ oligomers. (A): diffusion from the vehicle (5 min after injection) (B): signal in hippocampus (5 min after injection); (C): signals in brain parenchyma (60 min after injection). Animals were injected unilaterally with $7.5 \mu \mathrm{L}$ solution, the surgical procedure was the same as described in Materials and Methods.

\subsection{Studies on the Neurotoxic Effect of Two Different, Icv Administered Aß1-42 Aggregates into Rat Brains}

We demonstrated that $A \beta 1-42$ oligomers can reach the $\mathrm{HC}$ area after icv administration. The effect of different A $\beta 1-42$ oligomers ( $24 \mathrm{~h}$ and $168 \mathrm{~h}$ aggregation time in $25 \mu \mathrm{M}$ peptide concentration) was then studied. We analyzed the neuron viability with cresyl violet staining, tau level with tau-immunochemistry and the change of dendritic spine number was also measured. Our aim was to study if the A $\beta 1-42$ oligomers show neurotoxic effects in the HC.

In the experiment, three groups of rats were used: the $24 \mathrm{~h}$ and $168 \mathrm{~h}$ aggregated $\mathrm{A} \beta 1-42$ treated groups in the same concentration $(25 \mu \mathrm{M})$ as well as HCBS-treated control. Abbreviation used for oA $\beta$-assemblies were: $24 \mathrm{~h} / 25 \mu \mathrm{M}$ and $168 \mathrm{~h} / 25 \mu \mathrm{M}$.

\subsubsection{Histology}

After icv administration of oA $\beta 1-42$ rats, significant differences exist between groups in the number of neurons. Significantly more viable neurons were counted in the HCBS treated group than in the $168 \mathrm{~h} / 25 \mu \mathrm{M}$ group ( $p=0.001, n=4$ for each group, two slices/animal, Figure 3). (The $24 \mathrm{~h} / 25 \mu \mathrm{M}$ assembly did not cause a significant decrease.). Tau-immunochemistry showed neurotoxic effect in the A $\beta 1-42$ treated groups, significantly more abnormally accumulated TNFs could be detected in both A $1-42$ treated groups $(24 \mathrm{~h} / 25 \mu \mathrm{M}$ and $168 \mathrm{~h} / 25 \mu \mathrm{M})$ compared with the vehicle (HCBS) group (HCBS vs. $24 \mathrm{~h} / 25 \mu \mathrm{M} p=0.042$; HCBS vs. $168 \mathrm{~h} / 25 \mu \mathrm{M} \mathrm{oA} \beta 1-42 p=0.007, n=4$ for each group, four slices/animal, Figure 4). 


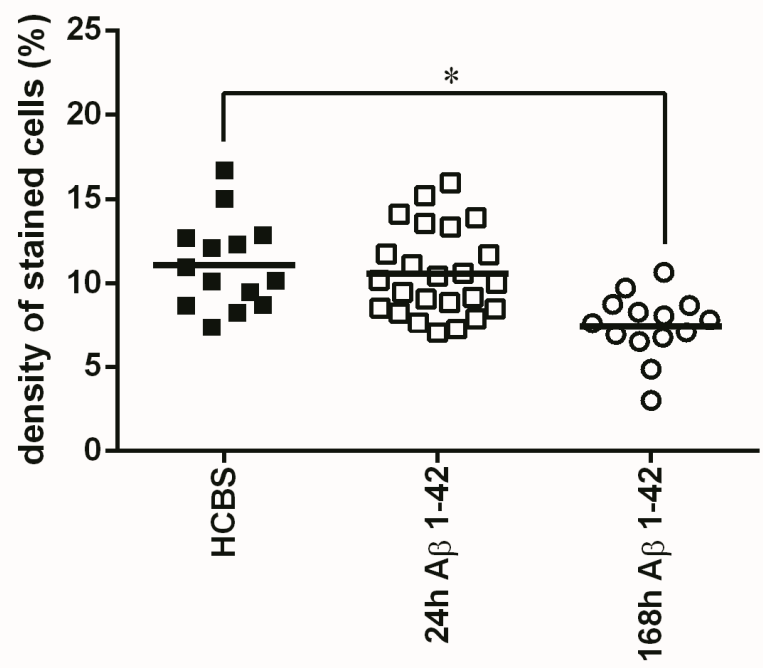

Figure 3. Cresyl violet staining of hippocampal slices after HCBS, $24 \mathrm{~h}$ aggregated and $168 \mathrm{~h}$ aggregated A $\beta 1-42$ treatment $(24 \mathrm{~h} / 25 \mu \mathrm{M}$ and $168 \mathrm{~h} / 25 \mu \mathrm{M})$. Each dot represents the counted raw data, while horizontal bars indicate mean values. Significant difference in staining density were observed when compared HCBS vs. $168 \mathrm{~h}$ aggregated A $\beta 1-42$ group $(p=0.001, n=4,2$ slices/animal; $n$ refers to the number of animals per group). Statistical significance was determined by one-way ANOVA, followed by Hochberg's GT2 post hoc test. * Differences with a $p$-value $<0.05$ were considered significant.

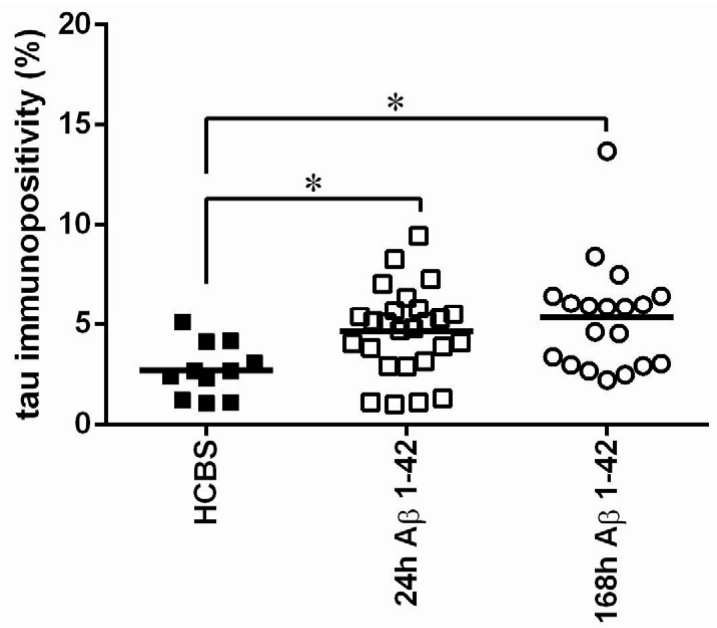

Figure 4. Tau-immunostaining of hippocampal slices after HCBS, $24 \mathrm{~h}$ aggregated and $168 \mathrm{~h}$ aggregated A $\beta 1-42$ treatment $(24 \mathrm{~h} / 25 \mu \mathrm{M}$ and $168 \mathrm{~h} / 25 \mu \mathrm{M})$. Each dot represents the counted raw data, while horizontal bars indicate mean values. Significant difference in the number of tau-immunopositive cells were observed between HCBS vs. $24 \mathrm{~h}$ A $\beta 1-42$ treated group and HCBS vs. $168 \mathrm{~h}$ A $\beta 1-42$ treated group, ( $p=0.042$ and $p=0.007$ respectively. $n=4,4$ slices/animal; $n$ refers to the number of animals per group). Statistical significance was determined by one-way ANOVA, followed by Hochberg's GT2 post hoc test. ${ }^{*}$ Differences with a $p$-value $<0.05$ were considered significant.

Representative examples of coronal HC sections (Figure 5) show the staining of neurons after $25 \mu \mathrm{M}$ A $31-42$ administration (A: control group, B: $24 \mathrm{~h}$ aggregation, C: $168 \mathrm{~h}$ aggregation assembly), and the abnormal aggregated NFTs (D: control group, E: $24 \mathrm{~h}$ aggregation, F: $168 \mathrm{~h}$ aggregation sample). 

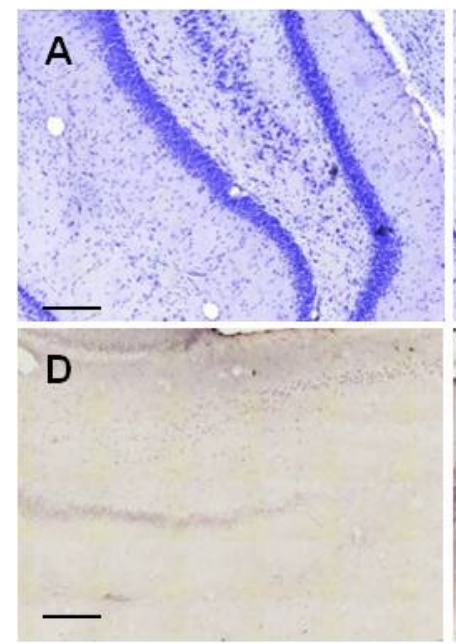
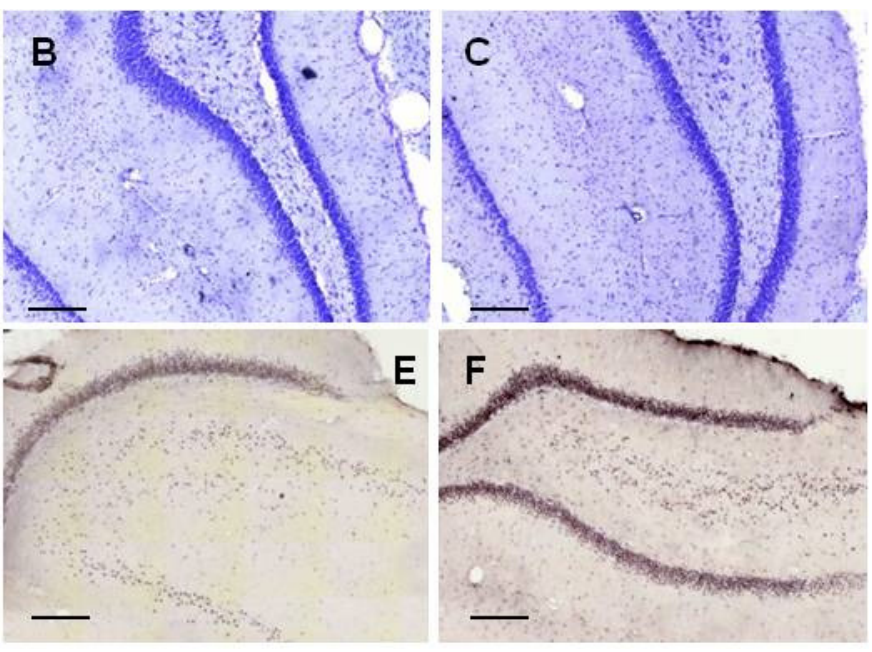

Figure 5. Representative coronal examples of hippocampcal sections stained with cresyl-violet (first row) to show the presence of neuron number (first row) and with tau-antibody to show the presence of abnormally aggregated NFTs (second row). (A,D): control group; (B,E): $24 \mathrm{~h}$ aggregated $25 \mu \mathrm{M}$ amyloid treated group; (C,F): $168 \mathrm{~h}$ aggregated $25 \mu \mathrm{M}$ amyloid treated group. Scale bar: $200 \mu \mathrm{m}$.

\subsubsection{Studying the Change of Dendritic Spine Density Using Golgi-Cox Impregnation}

The same three groups of animals $(24 \mathrm{~h} / 25 \mu \mathrm{M} ; 168 \mathrm{~h} / 25 \mu \mathrm{M}$ oA $31-42$ and HCBS-treated control) were used as in the former experiments. We found significant differences in spine density comparing the $168 \mathrm{~h}$ aggregated $\mathrm{A} \beta 1-42$ treated to the control group. The $168 \mathrm{~h} / 25 \mu \mathrm{M}$ oA $\beta 1-42$ injected group had significantly less dendritic spines than the HCBS-treated control group $(p=0.048$, Figure 6$)$. There was no significant difference in the $24 \mathrm{~h}$ aggregated A $\beta 1-42$ group compared with the controls. Representative photomicrographs demonstrated the difference between groups (Figure $6 \mathrm{C}-\mathrm{E}, n=2$, 2-2 slices/group and 3-3 neurons per slice).
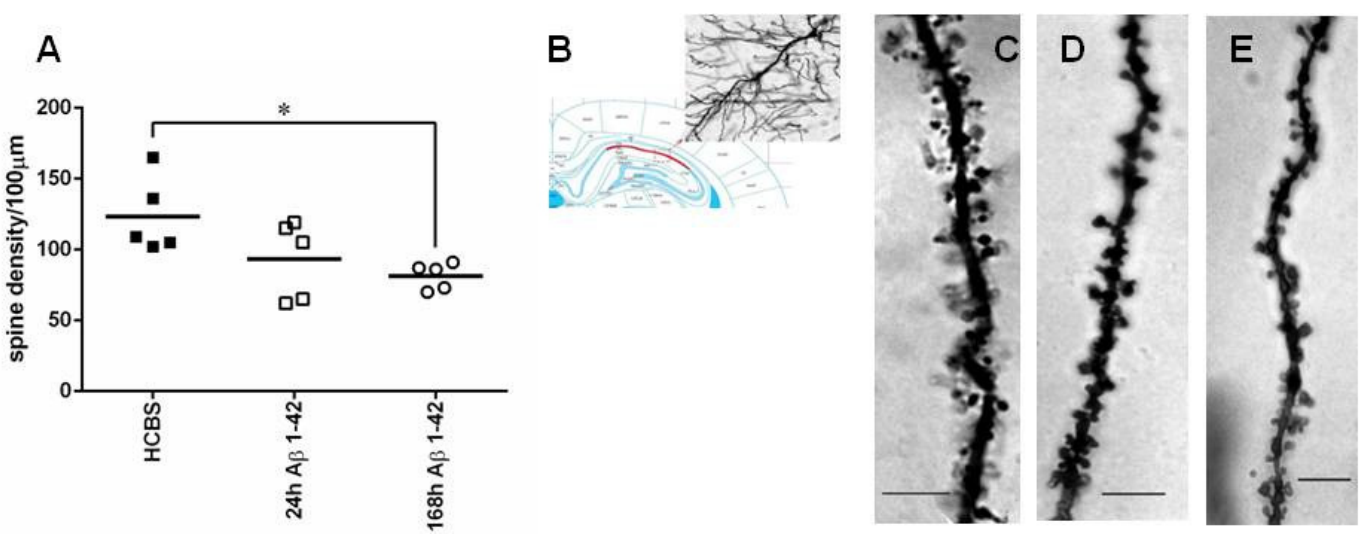

Figure 6. Representative examples of hippocampcal sections stained with Golgi-Cox method to show the presence of the prevailing changes in spine density after treatment with $24 \mathrm{~h}$ or $168 \mathrm{~h}$ aggregated $\mathrm{A} \beta 1-42(24 \mathrm{~h} / 25 \mu \mathrm{M}$ and $168 \mathrm{~h} / 25 \mu \mathrm{M})$. (A): apical dendritic spine density. Each dot represents the counted raw data, while horizontal bars indicate mean values. Significant difference in spine densities was observed between HCBS and $168 \mathrm{~h}$ aggregated oA $\beta 1-42$ treated groups $(p=0.048, n=2,2-2$ slices per group and 3-3 neurons per slice; $n$ refers to the number of animals per group). Statistical significance was determined by one-way ANOVA, followed by a Games Howell post hoc test. * Differences with a $p$-value $<0.05$ were considered significant; (B): $20 \times$ magnification of a CA1 subfield pyramidal neuron; (C): control (HCBS) group; (D): $24 \mathrm{~h}$ aggregated $25 \mu \mathrm{M}$ A $\beta 1-42$ treated group; (E): $168 \mathrm{~h}$ aggregated $25 \mu \mathrm{M}$ A $\beta 1-42$ treated group. Scale bar: $10 \mu \mathrm{m}$. 


\subsubsection{Electrophysiological Studies}

Ex vivo electrophysiological recordings with multi-electrode array (MEA) were performed in acute hippocampal slices in artificial cerebrospinal fluid (ACSF). After establishing a stable baseline, LTP was elicited by applying a theta-burst stimulation (TBS) protocol and followed for an hour. The average of the peak-to-peak amplitudes of fEPSPs before the LTP induction was taken as $100 \%$ (Figure 7). The slices obtained from HCBS-injected animals showed robust potentiation after TBS $(230 \pm 24 \%$; $n=5$ slices). The two groups of icv injected animals treated with $24 \mathrm{~h} / 25 \mu \mathrm{M}$ and $168 \mathrm{~h} / 25 \mu \mathrm{M}$ oA $\beta 1-42$ aggregates showed impairment of LTP. The $24 \mathrm{~h}$ A $\beta 1-42$ assemblies caused only a minor impairment ( $184 \pm 7 \% ; n=6$ slices), while the $168 \mathrm{~h}$ amyloid aggregates sled to a major disruption of potentiation $(145 \pm 11 \% ; n=6$ slices, Figure 7$)$.
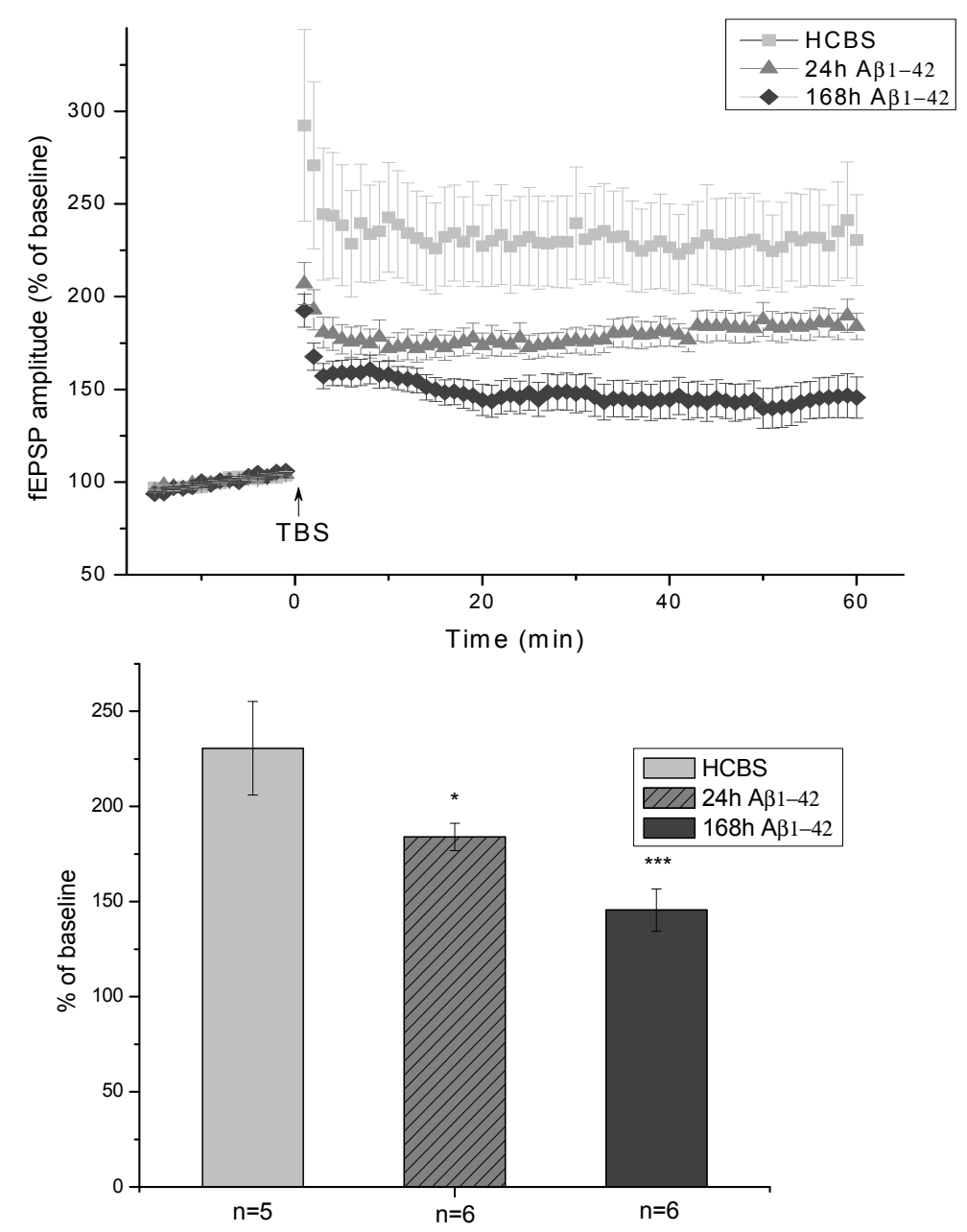

Figure 7. Shows the amplitude of fEPSPs normalized to pre-LTP control. The fEPSPs were recorded from the proximal stratum radiatum of CA1. The LTP of the $168 \mathrm{~h}$ oA $\beta 1-42$ treated animals showed robust impairment compared to HCBS treated ones, while the decrease was smaller in the group of $24 \mathrm{~h}$ oA $\beta 1-42$ injected rats. The histogram shows the level of LTP between 55 and 60 min post-TBS for each group. Error bars represent mean \pm SEM. ${ }^{*} p \leq 0.05$ and ${ }^{* * *} p \leq 0.001$.

\subsection{Systematic Studies for Finding the Most Toxic form of the A 1 1-42 Oligomers}

The influence of both the peptide concentration and the aggregation time on the toxicity of oA $\beta 1-42$ assemblies were studied in these experiments. Altogether, the effect of six different $A \beta 1-42$ assemblies were studied in the biological experiments (see Table 1). 
Table 1. Variation of aggregation time and concentration for systematic studies of the effect on toxic A $\beta 1-42$ aggregates used in biological experiments.

\begin{tabular}{ccc}
\hline Groups of $\mathbf{A} \boldsymbol{\beta}$-Treated Animals & Aggregation Time (Hour) & Concentration $(\boldsymbol{\mu M})$ of $\mathbf{A} \boldsymbol{\beta}$ during Aggregation \\
\hline $\mathrm{A}(n=11), 24 \mathrm{~h} / 25 \mu \mathrm{M}$ & 24 & 25 \\
$\mathrm{~B}(n=11), 24 \mathrm{~h} / 75 \mu \mathrm{M}$ & 24 & 75 \\
$\mathrm{C}(n=11), 24 \mathrm{~h} / 200 \mu \mathrm{M}$ & 24 & 200 \\
$\mathrm{D}(n=12), 168 \mathrm{~h} / 25 \mu \mathrm{M}$ & 168 & 25 \\
$\mathrm{E}(n=12), 168 \mathrm{~h} / 75 \mu \mathrm{M}$ & 168 & 75 \\
$\mathrm{~F}(n=12), 168 \mathrm{~h} / 200 \mu \mathrm{M}$ & 168 & 200 \\
\hline
\end{tabular}

The control groups ( $n=11$ and $n=12$, respectively) got icv HCBS solution.

2.3.1. AFM Studies of the Effect of the Concentration and the Aggregation Time on the Size of A $\beta 1-42$ Oligomers

As the morphological characterization of a mixed oligomer preparation of $A \beta 1-42$ is crucial for the better understanding of the biological effects exerted by the different types of oligomers, we conducted in vitro aggregation studies, in which different concentrations of $A \beta 1-42$ were incubated in physiologic buffers for an elongated period of time. Morphology and size of the aggregates were studied by atomic force microscopy (AFM) in tapping mode. The representative images showed that, under the applied conditions, mainly spherical oligomers were formed after $24 \mathrm{~h}$, the size of which did not depend considerably from the peptide concentration (Figure 8A-C) as average heights of the aggregates after $24 \mathrm{~h}$ of aggregation were as follows: (A) $6.5 \mathrm{~nm}$ in a $25 \mu \mathrm{M}$ solution; (B) $6.5 \mathrm{~nm}$ in $75 \mu \mathrm{M}$; (C) $10.3 \mathrm{~nm}$ in $200 \mu \mathrm{M}$. After $168 \mathrm{~h}$, besides the spherical oligomers, protofibrillar aggregates appeared at smaller concentrations $(25 \mu \mathrm{M}$ and $75 \mu \mathrm{M})$, while, in the extremely high $200 \mu \mathrm{M}$ concentration, we could experience the massive formation of large round aggregates, presumably due to the strong steric hindrance between the monomers in the overcrowded aggregation environment. The detected average heights were (D) $8.2 \mathrm{~nm}$ in $25 \mu \mathrm{M}$, (E) $8.0 \mathrm{~nm}$ in $75 \mu \mathrm{M}$, and (F) $21.5 \mathrm{~nm}$ in $200 \mu \mathrm{M}$, respectively. Biological effectiveness of these different aggregates was further studied in consecutive biological experiments.
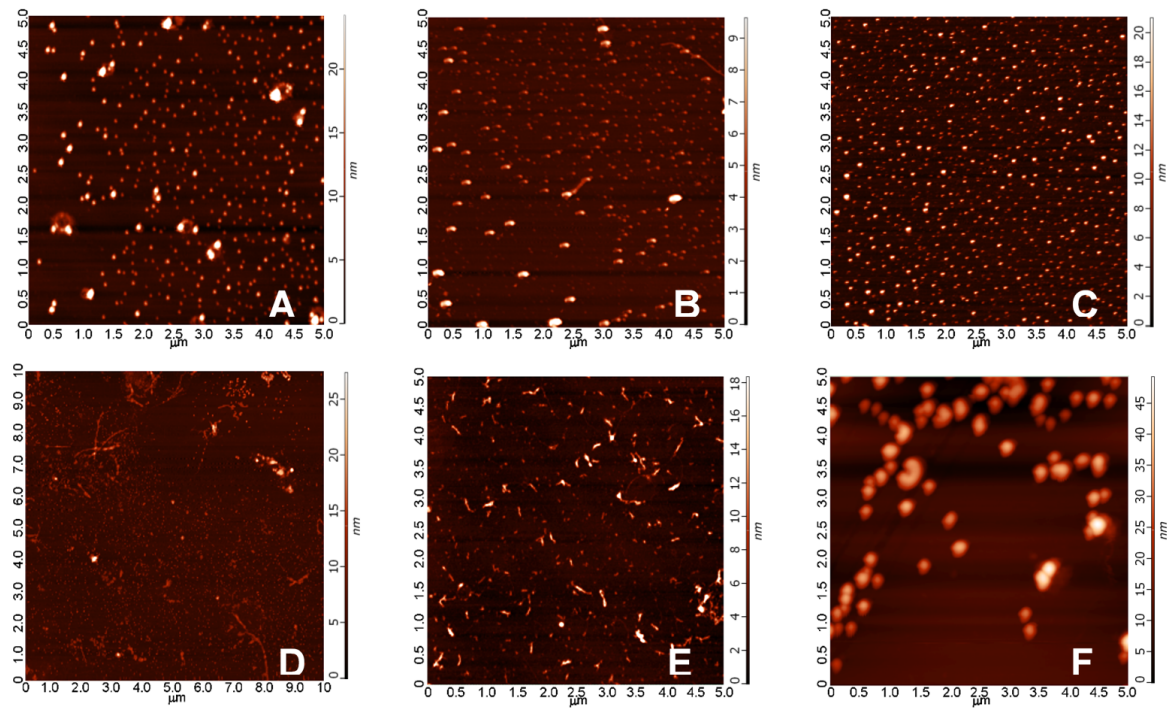

Figure 8. Morphology of A $\beta 1-42$ oligomers observed on a mica surface in AFM experiments. Average heights of the aggregates after $24 \mathrm{~h}$ of aggregation were as follows: (A) $6.5 \mathrm{~nm}$ in a $25 \mu \mathrm{M}$ solution; (B) $5.4 \mathrm{~nm}$ in $75 \mu \mathrm{M}$; (C) $10.3 \mathrm{~nm}$ in $200 \mu \mathrm{M}$. After $168 \mathrm{~h}$, the following average heights were detected (D) $8.2 \mathrm{~nm}$ : in $25 \mu \mathrm{M}$; (E) $8.0 \mathrm{~nm}$ in $75 \mu \mathrm{M}$; (F) $21.5 \mathrm{~nm}$ in $200 \mu \mathrm{M}$. An elongated incubation resulted in the formation of protofibrillar aggregates besides the spherical ones, as it could be observed in images (D,E). 


\subsubsection{Spatial Navigation in Morris Water Maze}

The Morris water maze (MWM) task was used to assess spatial learning and memory. MWM is one of the most commonly used experimental models for rodents to measure spatial learning and memory [59-64]. The total time spent in arena from first trials (time spent with searching the platform) was the most informative data. The results are represented in Figures 9 and 10.

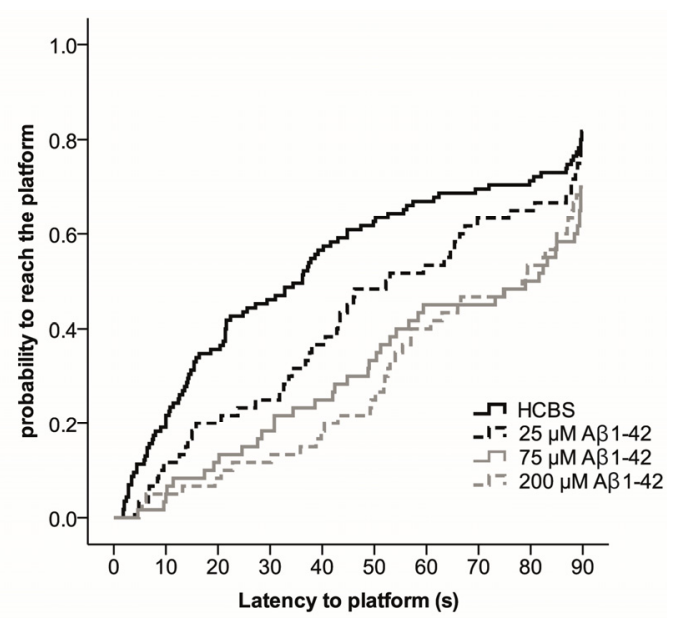

Figure 9. Effect of different aggregation concentrations (25, 75 and $200 \mu \mathrm{M})$ of synthetic A $\beta 1-42$ (24 h aggregation time) on Morris water maze performance. The fitted survival curves using the Cox Proportional Hazard model represents the probability that animals find the platform during a trial, capped at 90 s. We compared HCBS vs. $25 \mu \mathrm{M}$ oA $\beta 1-42(p=0.219)$, HCBS vs. $75 \mu \mathrm{M}$ oA $\beta 1-42(p=0.003)$, and HCBS vs. $200 \mu \mathrm{M} \mathrm{oA} \beta 1-42(p=0.001)$ treatment groups using log-rank tests $(n=12$ /group, except the HCBS group, where $n=23$ ).

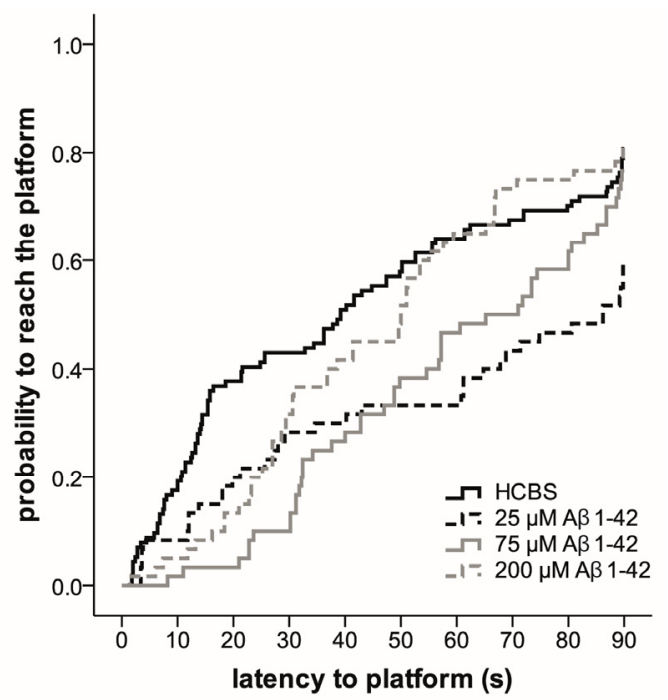

Figure 10. Effect of different aggregation concentrations (25, 75 and $200 \mu \mathrm{M})$ of synthetic A $\beta 1-42$ (168 h time) on Morris water maze performance. The fitted survival curves using the Cox Proportional Hazard model represents the probability that animals find the platform during a trial, capped at $90 \mathrm{~s}$. We compared HCBS versus $25 \mu \mathrm{M}$ oA $\beta 1-42(p=0.001)$, HCBS vs. $75 \mu \mathrm{M}$ oA $\beta 1-42(p=0.053)$, and HCBS versus $200 \mu \mathrm{M}$ oA $\beta 1-42(p=0.534)$ treatment groups using log-rank tests $(n=12$ /group, except HCBS group, where $n=23$ ). 
Compared to day one of testing, in the lower aggregation grade ( $24 \mathrm{~h}$ aggregation), the $75 \mu \mathrm{M}$ A $\beta 1-42$ treated Group B $(p=0.003)$ and $200 \mu \mathrm{M}$ A $\beta 1-42$ treated Group $C(p=0.001)$ rats were more likely to find the platform on day four $(p<0.001)$ and five $(p<0.001)$ than the HCBS treated group; however, the change was not significant on day two $(p=0.959)$ and three $(p=0.06)$. The probability to reach the platform was determined using the Cox Proportional Hazard model (Figure 9).

Compared to day one of testing, the rats in the $168 \mathrm{~h} / 25 \mu \mathrm{M}$ oA $\beta 1-42$ treated Group $D(p=0.001)$ found the platform more likely on day two $(p=0.002)$, three $(p<0.001)$, four $(p \leq 0.001)$ and five $(p<0.001)$. The probability to reach the platform was determined using the Cox Proportional Hazard model (Figure 10).

\subsubsection{Histology}

Histochemical studies in the hippocampal region confirmed our behavioral results. Although no significant difference was found between the treatment groups in the number of viable neurons after administration of $24 \mathrm{~h}$ aggregated oA $\beta 1-42$ oligomers, there was a tendency that suggested that the increasing aggregation concentration of $A \beta 1-42$ samples resulted in decreasing number of viable neurons in the examined area $(n=4 ; 2$ slices/animal, Figure 11). Significant difference appeared between the $168 \mathrm{~h}$ aggregation time groups: significant loss of viable neurons was found in the hippocampal area between all oA $\beta 1-42$ treated groups $(D-F)$ compared to the control HCBS group (HCBS vs. $25 \mu \mathrm{M} p=0.011$; HCBS vs. $75 \mu \mathrm{M} p<0.001$; HCBS vs. $200 \mu \mathrm{M} p<0.001 ; n=4$, 2 slices/animals, Figure 12).

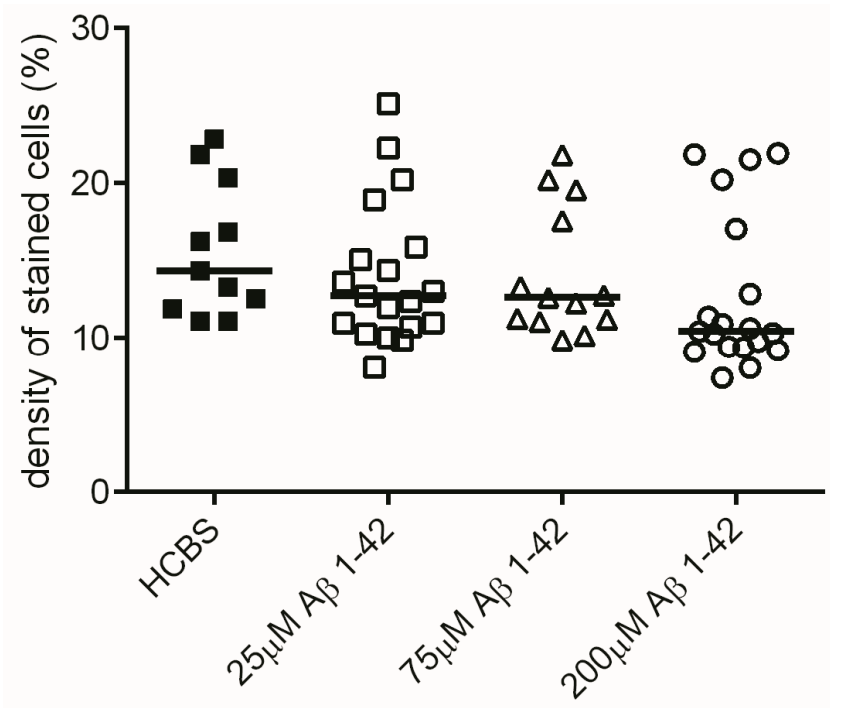

Figure 11. Cresyl violet staining (of hippocampal slices after treatment with different aggregation concentrations $(25,75$ and $200 \mu \mathrm{M})$ of $A \beta 1-42$ at a $24 \mathrm{~h}$ aggregation time. Each dot represents the counted raw data, while horizontal bars indicate median values. No significant difference in staining density, only a clear tendency of decrease was observed among the treatment groups compared to the HCBS group at the 0.05 significance level, $n=4,2$ slices/animal; $n$ refers to the number of animals per group. Statistical significance was determined by the nonparametric independent-samples Kruskal-Wallis test. 


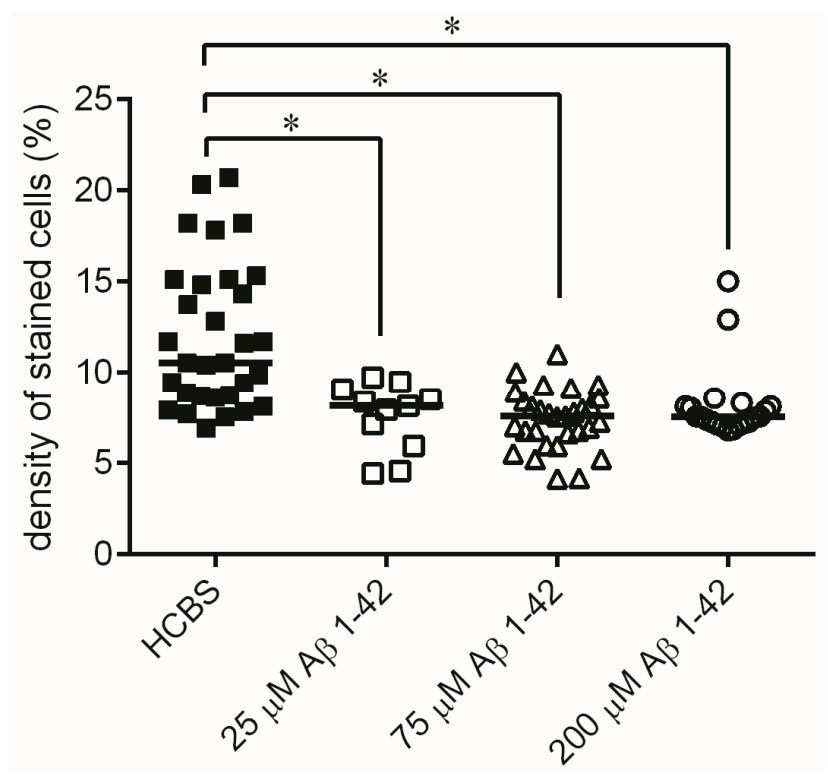

Figure 12. Cresyl violet staining of hippocampal slices after treatment with $168 \mathrm{~h}$ aggregated $\mathrm{oA} \beta$ assemblies using increasing aggregation concentrations $(25,75$ and $200 \mu \mathrm{M})$ of synthetic A $\beta 1-42$. Each dot represents the counted raw data, while horizontal bars indicate median values. Significant differences in the staining density were observed between HCBS and the $25 \mu \mathrm{M}$ A $\beta 1-42$ treated group ( $p=0.011)$, HCBS and the $75 \mu \mathrm{M}$ A $\beta 1-42$ treated group $(p<0.001)$, as well as between HCBS and the $200 \mu \mathrm{M}$ A $\beta 1-42$ treated group $(p<0.001), n=4,2$ slices/animal; $n$ refers to the number of animals per group. Statistical significance was determined by a nonparametric independent-samples Kruskal-Wallis test. ${ }^{*}$ Differences with a $p$-value $<0.05$ were considered significant.

Monitoring the presence of abnormally accumulated TNFs and comparing to the control group, significantly higher number of tau-immunopositive cells were observed in the $24 \mathrm{~h} / 200 \mu \mathrm{M}$ treated Group $C(p=0.015, n=4,4$ slices/animal, Figure 13), the $168 \mathrm{~h} / 25 \mu \mathrm{M}$ treated Group $D(p<0.001$, Figure 14) and the $168 \mathrm{~h} / 75 \mu \mathrm{M}$ Group $E,(p<0.001, n=4,4$ slices/animal, Figure 14) treated groups.

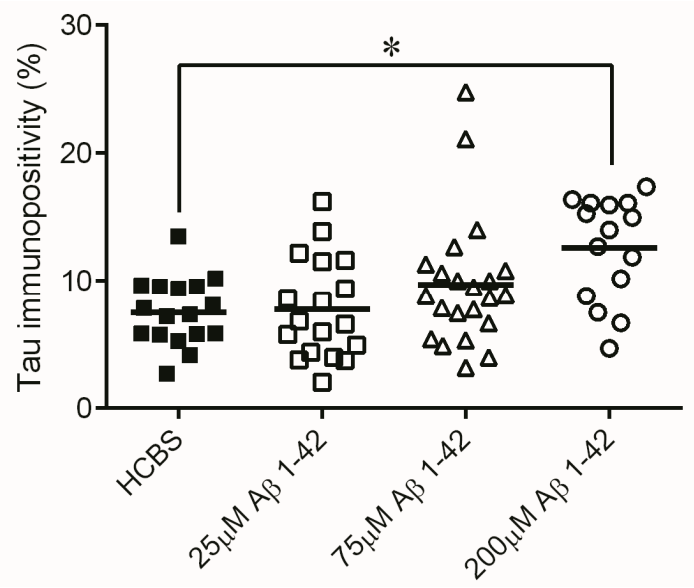

Figure 13. Tau-immunostaining of hippocampal slices after treatment with $24 \mathrm{~h}$ aggregated oA $\beta$ assemblies using increasing aggregation concentrations $(25,75$ and $200 \mu \mathrm{M})$ of $\mathrm{A} \beta 1-42$ treatment. Each dot represents the counted raw data, while horizontal bars indicate mean values. Significant difference in the number of tau-immunopositive cells were observed only between the HCBS and the $200 \mu \mathrm{M}$ A $\beta 1-42$ treated group ( $p=0.015, n=4$, 4 slices/animal; $n$ refers to the number of animals per group) Statistical significance was determined by one-way ANOVA, followed by Hochberg's GT2 post hoc test. ${ }^{*}$ Differences with a $p$-value $<0.05$ were considered significant. 


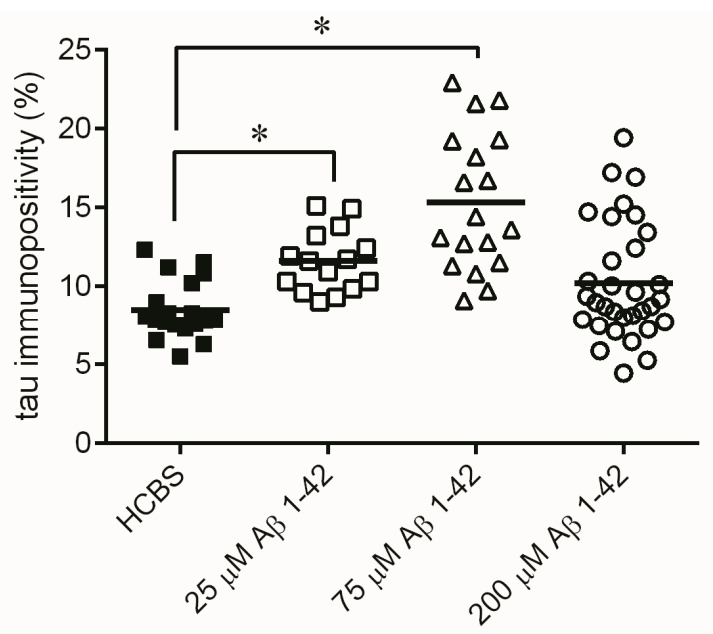

Figure 14. Tau-immunostaining of hippocampal slices after treatment of $168 \mathrm{~h}$ aggregated $\mathrm{A} \beta$ assemblies using increasing aggregation concentrations $(25,75$ and $200 \mu \mathrm{M})$ of synthetic $A \beta 1-42$. Each dot represents the counted raw data, while horizontal bars indicate mean values. Increasing number of tau immunopositive cells were observed comparing the HCBS and the $25 \mu \mathrm{M}$ oA $\beta 1-42$ treated $(p<0.001)$, as well as the HCBS and the $75 \mu \mathrm{M}$ oA $\beta 1-42$ treated groups $(p<0.001)$. There is no significant difference between HCBS and $200 \mu \mathrm{M}$ oA $\beta 1-42$ treated groups $(p=0.284), n=4,4$ slices/animal; $n$ refers to the number of animals per group. Statistical significance was determined by one-way ANOVA, followed by a Games-Howell post hoc test. * Differences with a $p$-value $<0.05$ were considered significant.

Representative examples of coronal HC sections show neurons after 25, 75 and $200 \mu \mathrm{M}$ oA $\beta 1-42$ administration with $24 \mathrm{~h}$ aggregation time (Figure 15A-D) using cresyl violet staining. The abnormal aggregated NFTs are demonstrated in Figure 15E-H). 

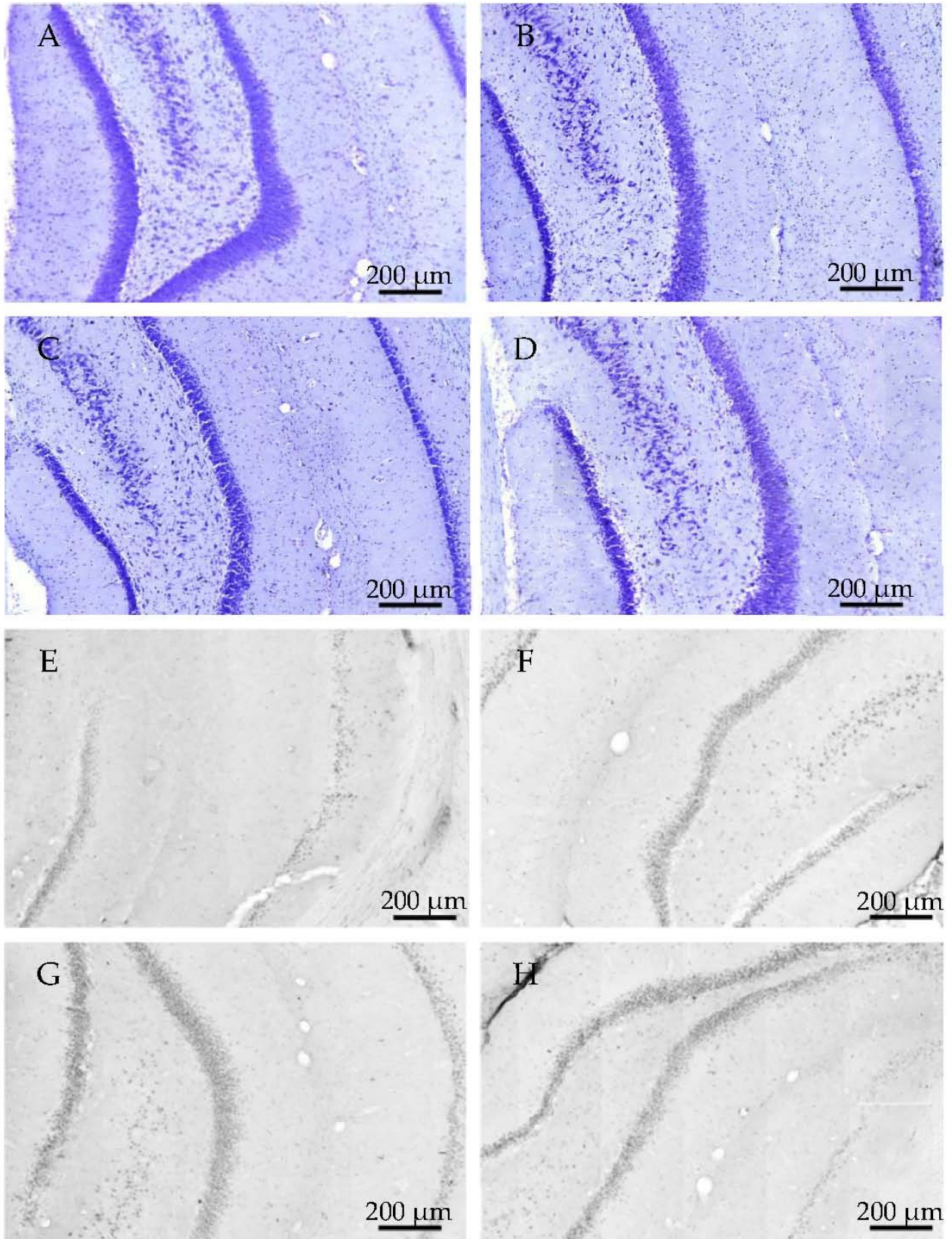

Figure 15. Representative examples of hippocampcal sections in $24 \mathrm{~h}$ aggregation groups, using cresyl-violet staining, show the change of viable neuron number (A-D). Immunochemistry with tau-antibody shows the presence of abnormally aggregated NFTs (E-H). (A,E): control group; (B,F): $25 \mu \mathrm{M}$ concentration; (C-G): $75 \mu \mathrm{M}$ concentration; (D-H): $200 \mu \mathrm{M}$ concentration.

Representative examples of coronal HC sections show the presence of neurons after 25, 75 and $200 \mu \mathrm{M}$ oA $\beta 1-42$ administration with $168 \mathrm{~h}$ aggregation time (A-D), using cresyl violet staining. The abnormally aggregated NFTs are shown in Figure 16. 

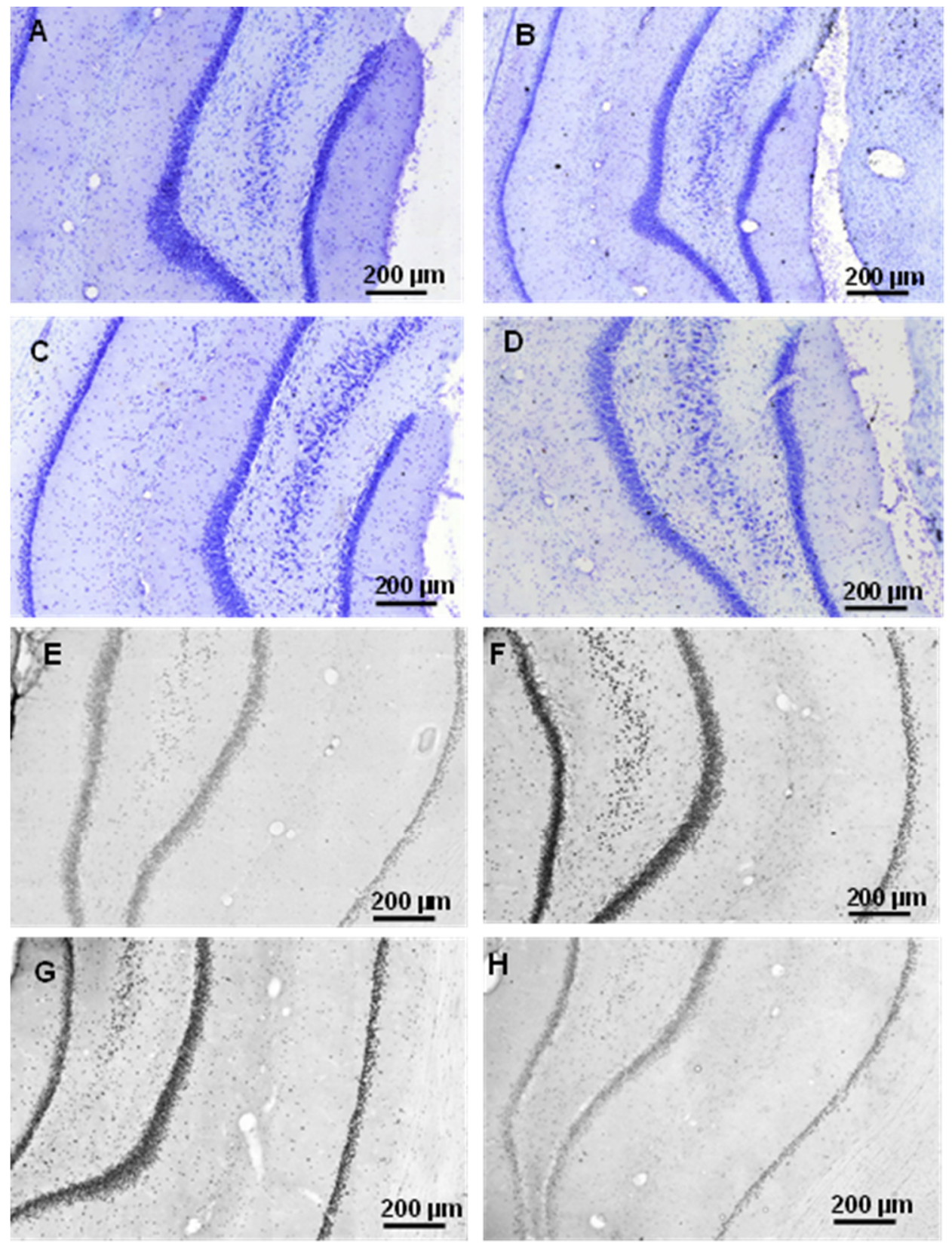

Figure 16. Representative examples of hippocampcal sections in $168 \mathrm{~h}$ aggregation time groups using cresyl-violet staining to show the decrease of viable neuron number (A-D). Immunochemistry with tau-antibodies shows the increase of abnormally aggregated NFTs (E-H). (A,E): control group; (B,F): $25 \mu \mathrm{M}$ concentration; (C-G): $75 \mu \mathrm{M}$ concentration; (D-H): $200 \mu \mathrm{M}$ concentration.

\subsubsection{Ex Vivo Electrophysiological Recordings with Multi-Electrode Array (MEA)}

The electrophysiological studies in the hippocampal region confirm our behavioral and immunohistochemical results. Slices were prepared from rats that had received icv administration of $24 \mathrm{~h} / 25 \mu \mathrm{M}$ (Group A) and $24 \mathrm{~h} / 75 \mu \mathrm{M}$ oA $\beta 1-42$ (Group B). Both oA $\beta 1-42$ samples caused reduced potentiation after LTP induction (168 $\pm 8 \%$ and $185 \pm 10 \%, n=6$ and 10, respectively) compared to the HCBS treated group ( $233 \pm 26 \%, n=5$, Figure 17). The $24 \mathrm{~h} / 200 \mu \mathrm{M}$ oA $\beta$ peptide (Group C) caused the greatest reduction of LTP level (136 $\pm 3 \%, n=8$, Figure 17). 


\section{$24 \mathrm{~h}$ aqareqation}
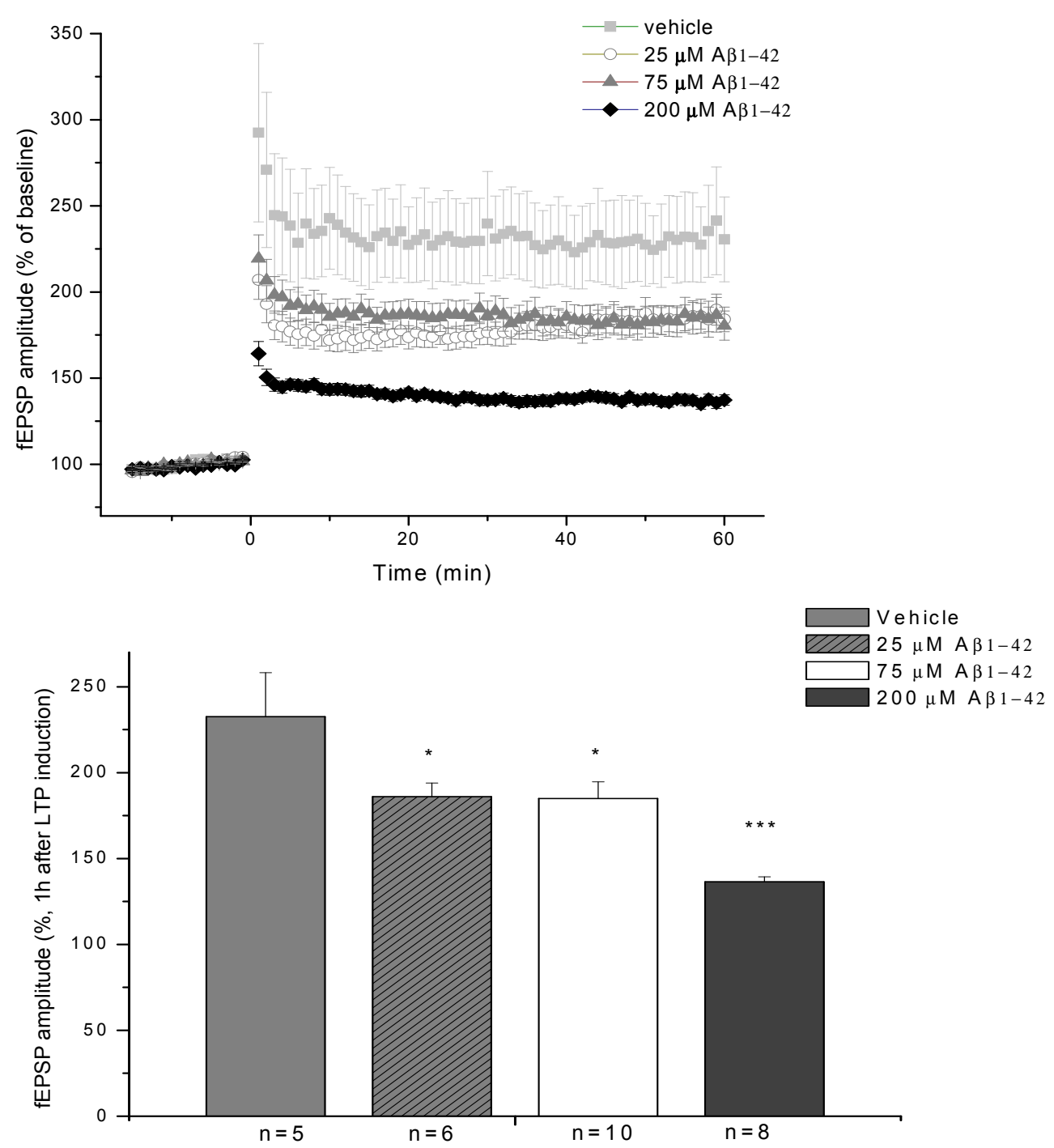

Figure 17. LTP impairment depends on the aggregation concentration. The effect of $24 \mathrm{~h} / 75 \mu \mathrm{M}$, $24 \mathrm{~h} / 25 \mu \mathrm{M}$ and $24 \mathrm{~h} / 200 \mu \mathrm{M}$ oA $\beta$ samples on LTP in HC slices. The histogram shows the level of fEPSP potentiation between 55 and 60 min post-TBS. Error bars represent mean \pm SEM. ${ }^{*} p \leq 0.05$ and $* * * \leq 0.001$.

The effect of the $168 \mathrm{~h}$ aggregates also showed concentration dependence (Figure 18). Similarly to the $24 \mathrm{~h}$ aggregation experiments, the effects of $25 \mu \mathrm{M}$ (Group D) and $75 \mu \mathrm{M}$ (Group E) peptide assemblies did not differ from each other, as they similarly reduced LTP level (145 $\pm 11 \% ; n=6$ and $145 \pm 4 \% ; n=12$, respectively). In contrast, the $168 \mathrm{~h} / 200 \mu \mathrm{M}$ (Group F) oA $\beta$ aggregates caused much smaller reduction of LTP ( $182 \pm 9 \% ; n=5$ compared to HCBS group $232.5 \pm 26 \% ; n=5)$. 


\section{$168 \mathrm{~h}$ aggregation}
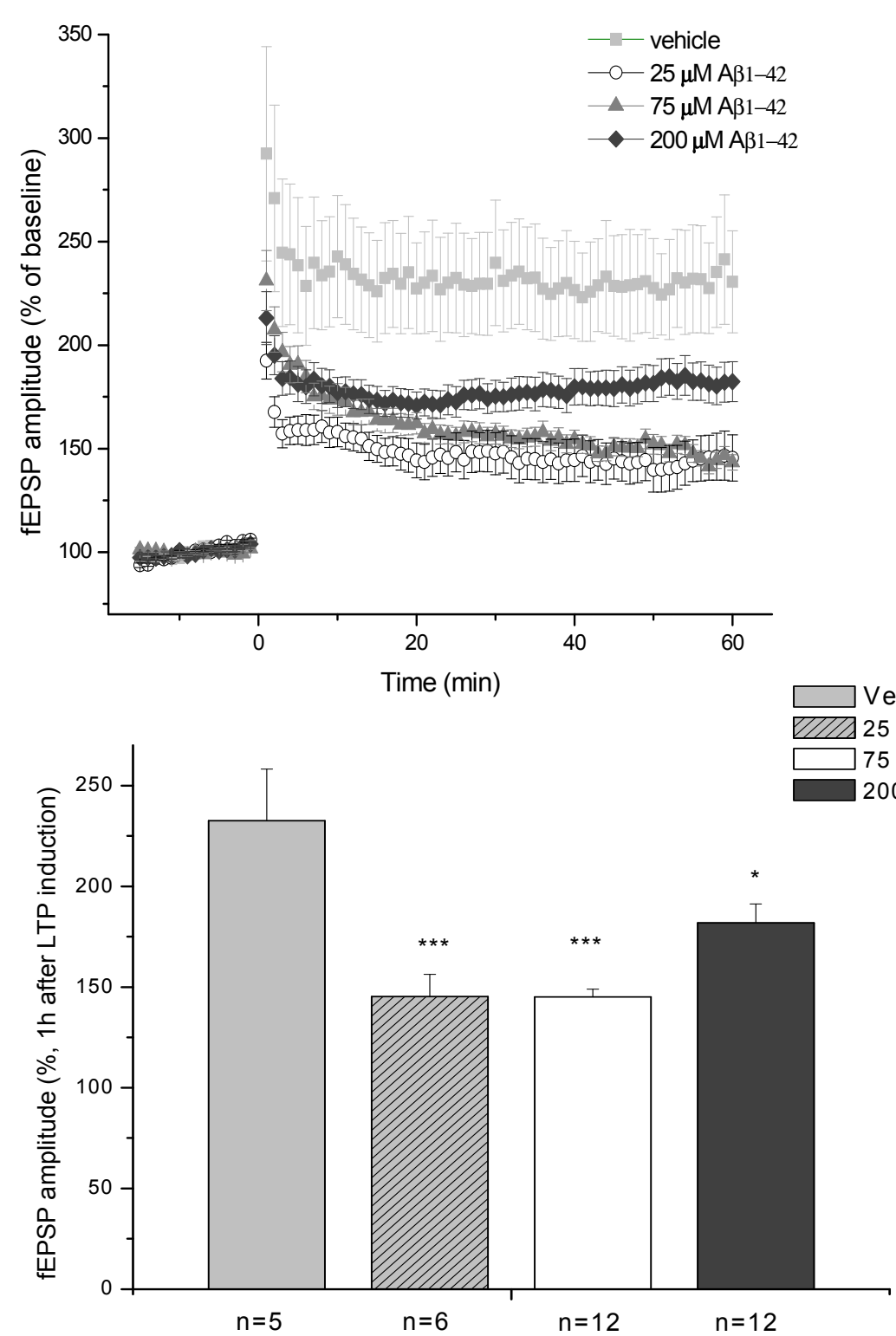

Figure 18. LTP impairment depends on the aggregation concentration of A $\beta 1-42$. The effect of $168 / 25 \mu \mathrm{M}, 168 \mathrm{~h} / 75 \mu \mathrm{M}$ and $168 / 200 \mu \mathrm{M}$ oA $\beta 1-42$ samples in acute HC slices. The histogram shows the level of fEPSP potentiation between 55 and 60 min post-TBS. Error bars represent \pm SEM. ${ }^{*} p \leq 0.05$ and ${ }^{* * *} p \leq 0.001$.

\section{Discussion}

The main aim of the present work was a systematic study of the neurotoxic effects of icv administered oA $\beta$ assemblies in rat brain. Our principal aims were:

(1) Preparation of toxic $A \beta 1-42$ oligomers from a precursor peptide (iso-A $\beta 1-42)$ and standardization of the method of the synthesis and characterization of oA $\beta 1-42$ assemblies.

(2) Measurement of the effect of different oA $\beta 1-42$ samples on neuron viability, NFT-formation, dendritic spine density, synaptic plasticity and spatial behavior in nontransgenic rats.

(3) Development of a novel rat model of AD using icv administration of well-characterized oA $\beta 1-42$ samples. 
The role of amyloid plaques and oligomeric $\mathrm{A} \beta$ in $\mathrm{AD}$ etiopathology has been debated for a long time. Depositions of extracellular $A \beta$ and the surrounding oA $\beta$ are considered as trigger signals to induce dendritic spine loss and synaptic dysfunction in AD. A $\beta$ assemblies are synaptotoxic, and dendritic spine loss is strongly correlated with cognitive impairment in AD. A $\beta$ has been shown to target synapses $[65,66]$. Experiments demonstrated that synapse dysfunction was triggered by $A \beta$ oligomers [67]. Bilateral intrahippocampal (ihc) injections of fibrillar $A \beta$ reduced neuronal density, increased the intensity of glial fibrillary acidic protein and caused behavior performance deficits $[49,68]$. Our former experiments also demonstrated that synthetic $\mathrm{fA} \beta$ after ihc administration simultaneously decreased spatial learning ability in MWsM and reduced dendritic spine density in the rat hippocampus CA1 region [69]. As $\mathrm{fA} \beta$ is a non-diffusible form and act only locally, the diffusible oligomeric $A \beta$ assemblies (that surround $f A \beta$ ) very probably affect the neurons and synapses in these experiments [70]. It is widely accepted that accumulation of soluble toxic $A \beta$ at the synapse may be on the critical path to neurodegeneration [71]. A $\beta$-dependent disruption of neural cell adhesion molecules in $\mathrm{AD}$ hippocampus may contribute to synapse loss [72,73].

In our former studies, we found that the aggregation grade of the oligomeric $A \beta 1-42$ samples plays a crucial role in the toxicity $[53,54]$. We demonstrated that the aggregation grade can be standardized using controlled in situ preparation of $A \beta 1-42$ oligomers from the $A \beta$-precursor isopeptide (iso-A $\beta 1-42$ ), and oA $\beta 1-42$ assemblies can be physicochemically characterized [74]. This method was used in the present work for preparation of different oA $\beta 1-42$ assemblies in two series of experiments. Different aggregation times $(24 \mathrm{~h}$ and $168 \mathrm{~h})$ and peptide concentrations $(25 \mu \mathrm{M}$, $75 \mu \mathrm{M}, 200 \mu \mathrm{M})$ were used, and the AFM method was applied for characterization of oA $\beta$ assemblies.

In the first experiment, one peptide concentration $(25 \mu \mathrm{M})$ and two different aggregation times ( $24 \mathrm{~h}$ and $168 \mathrm{~h}$ ), in the second experiment three peptide concentrations $(25 \mu \mathrm{M}, 75 \mu \mathrm{M}$ and $200 \mu \mathrm{M})$ and two different aggregation times ( $24 \mathrm{~h}$ and $168 \mathrm{~h}$ ) were used. (The samples of the oA $\beta 1-42$ were signed as $24 \mathrm{~h} / 25 \mu \mathrm{M}, 168 \mathrm{~h} / 25 \mu \mathrm{M}, 24 \mathrm{~h} / 75 \mu \mathrm{M}, 168 \mathrm{~h} / 75 \mu \mathrm{M}, 24 \mathrm{~h} / 200 \mu \mathrm{M}, 168 \mathrm{~h} / 200 \mu \mathrm{M}$.). The morphology of some of the oA $\beta 1-42$ assemblies is shown in Figure 8.

A pilot study (Figures 1 and 2) demonstrated that AMCA-labeled fibrillary A $\beta 1-42$ remained in the ventricles after injection, but AMCA-oA $\beta 1-42$ penetrated across the ependyma or entered the brain parenchyma by the glymphatic flow.

The results of the first experiments are shown in Figures 3-7. There was a considerable difference between the effects of the two oA $\beta 1-42$ samples: the $168 \mathrm{~h} / 25 \mu \mathrm{M}$ sample showed significant change in neuronal viability ( $p=0.001$, Figure 3$)$, increase in NFT-level ( $p=0.007$, Figures 4 and 5$)$, decrease of dendritic spine density (Figure $6, p=0.048$ ) and robust impairment of LTP (Figure 7, $p<0.001$ ). The effects of $24 \mathrm{~h} / 25 \mu \mathrm{M}$ sample were not significant in the viability test (Figures 3 and $5 \mathrm{~B}$ ), as well as in dendritic spine density measurement (Figure 6A). These results demonstrated that the aggregation time of A $\beta 1-42$ plays a crucial role in the formation of toxic assemblies. In addition, $168 \mathrm{~h}$ aggregation time in $25 \mu \mathrm{M}$ concentration resulted in the formation of toxic assemblies, while the $24 \mathrm{~h}$ samples gave less toxic aggregates.

In the second series of experiments, the effect of six different oA $\beta 1-42$ samples were systematically studied. AFM studies of these oA $\beta 1-42$ samples demonstrated big differences in the size of the assemblies (Figure 8). The mean of the particle diameter was in the range of 6.5 and $21.5 \mathrm{~nm}$. Besides the obvious differences in size, an altered morphology of the aggregates could also be observed, as protofibrils were formed together with the spherical oligomers in lower $(25$ and $75 \mu \mathrm{M})$ concentrations after $168 \mathrm{~h}$. These oA $\beta 1-42$ assemblies were used in behavioral (learning and memory), histological and electrophysiological studies.

In this series of experiments, we examined whether these $A \beta$ oligomers impair memory functions in rats, especially the spatial memory. We measured the effect of icv administered oA $\beta$ samples in MWM, a hippocampal learning and memory test, in which the animals have to learn the location of the hidden platform [60]. As HC appears to play a central role for establishment in long-term memory [75], 
we determined the mean of the first swimming session. The second trial every day was a potentiation for the animals to learn the exercise easier.

Finding of the hidden platform took a longer time for the $A \beta$-treated animals. After latency times of five days, A $\beta 1-42$-treated animals exhibited significant differences compared to the control group. This finding is in accordance with the hypothesis that icv injection of iso-A $\beta 1-42$ derived oligomers impair the spatial memory. The highest significance (greatest difference in latency times) compared with the control animals was exhibited by the group $C(24 \mathrm{~h} / 200 \mu \mathrm{M})$, where the particle size was $10 \mathrm{~nm}$ (Figures 8 and 9), the group $D(25 \mu \mathrm{M}$ and $168 \mathrm{~h}$ ), where the particle size exceeds $8 \mathrm{~nm}$ (Figures 8 and 10).

Histological studies partly confirmed the results of behavioral experiments. Although the $24 \mathrm{~h}$ aggregates did not significantly decrease the number of viable neurons, there was a clear tendency for neuronal loss (Figure 11). The $168 \mathrm{~h}$ samples cause a significant decrease of viable neurons compared to the control (Figure 12).

Measurement of the abnormally accumulated NFTs in the HC slices gave interesting results (Figure 13): only the $24 \mathrm{~h} / 200 \mu \mathrm{M}$ oA $\beta 1-42$ assembly caused significant NFT accumulation. Aggregation time of $168 \mathrm{~h}$ in 25 and $75 \mu \mathrm{M}$ concentrations resulted in the formation of toxic assemblies, but the $168 \mathrm{~h} / 200 \mu \mathrm{M}$ sample did not cause a change in the NFT level (Figure 14). These results were in good correlation with the size and mobility of oA $\beta$ assemblies (Figure 8). Representative examples showed the coronal HC sections, applied for neuron viability and NFT-accumulation measurements (Figures 15 and 16).

Electrophysiological studies also supported the results of the behavioral experiments. Only the $24 \mathrm{~h} / 200 \mu \mathrm{M}$ oA $31-42$ sample caused a great reduction in LTP, although the samples with lower aggregation concentrations also showed a clear tendency for decreasing LTP (Figure 17). Finally, the concentration dependence in the $168 \mathrm{~h}$ groups was similar to the $24 \mathrm{~h}$ groups: the 25 and $75 \mu \mathrm{M}$ oA $\beta 1-42$ samples caused robust and significant reduction, while the LTP reduction was much smaller in the $200 \mu \mathrm{M}$ group (Figure 18). These results also correlate well with the size and viability of the $\mathrm{oA} \beta$ assemblies.

Summarizing our studies, we found a simple correlation between the aggregation size and the mobility and toxicity of oA $\beta 1-42$. There was an optimal size of oA $\beta 1-42$ assemblies (between 8 to $10 \mathrm{~nm}$ height $)$ that caused elevated toxicity $(24 \mathrm{~h} / 200 \mu \mathrm{M}, 168 \mathrm{~h} / 25 \mu \mathrm{M}$ and $168 \mathrm{~h} / 75 \mu \mathrm{M}$ aggregates, (Figures 9, 10, 12-14, 17 and 18). Too small and too big aggregates $(24 \mathrm{~h} / 25 \mu \mathrm{M}, 24 \mathrm{~h} / 75 \mu \mathrm{M}$, $168 \mathrm{~h} / 200 \mu \mathrm{M}$ ) were less toxic or nontoxic (Figures 9, 11, 13, 14, 17 and 18). We assume that the size and different conformations, resulting in altered morphology, together are responsible for the enhanced toxicity. In addition, the peptide conformation within the oA $\beta 1-42$ samples is unknown, and we suppose that the toxic samples not only have similar particle size, but also structural similarity, containing oligomeric and protofibrillar $\mathrm{A} \beta 1-42$ species.

The connection between amyloid aggregation, cellular toxicity and the biochemistry of neurodegeneration has been a challenge, and the molecular details are more or less unknown. Determining the biophysical properties and conformational variety of a single species of amyloid peptides/proteins represents a high experimental challenge. The main problem is the heterogeneous nature and the nanoscale dimensions of the amyloid assemblies. Circular dichroism and infrared spectroscopy are bulk techniques and cannot characterize the inner properties of the aggregates at the single species level [57].

Taken together, the suitability of a new rat model was demonstrated. Our aim was to work out a novel, robust AD rat model using icv administration of well characterized oligomeric A $\beta$ 1-42. Such kind of model has several advantages compared to the existing mice and rat models:

(1) Mice are typically more variable in their behavior than rats; thus, we were able to use fewer animals for getting significant results in rats than in mice in MWM and other behavior experiments. 
(2) Rats are physiologically, genetically and morphologically closer to humans than mice [46]. Their larger body and brain size facilitate neurosurgical procedures, neuroimaging and in vivo electrophysiology.

(3) Our research group also successfully used intranasal delivery of human $A \beta 1-42$ for rat brain targeting, but intranasal administration is complicated and very time-consuming.

(4) The recent method is a short-term model: it is possible to get pathology and behavior changes within two weeks after the icv administration into rats.

(5) Several laboratories have used short human $A \beta$ fragments (e.g., $A \beta 25-35$ ) in rat experiments; however, these kinds of short $A \beta$ peptides are not natural metabolites of $A \beta$ degradation, only aggregation-prone synthetic products.

(6) Other laboratories (e.g., [49]) used a rat model of AD injecting fibrillary $A \beta 1-42$ into the rat brain. In this model, the injected fibrillar $A \beta$ aggregates form a deposit in the brain and a long time is necessary for destabilization and disintegration of the assemblies to diffusible toxic $A \beta$-oligomers. The use of icv administration of toxic oA $\beta 1-42$ samples is advantageous, and the optimal size of the $\mathrm{A} \beta 1-42$ assemblies is 8 to $10 \mathrm{~nm}$ height.

Our current study demonstrated that icv administration of oA $\beta$ assemblies or $\mathrm{A} \beta$ protofibrils of definite size and structure into rats decreased cell viability and dendritic spine density, increased NFT formation, disturbed synaptic plasticity and impaired the learning and spatial behavior of the animals. Our results improve the "icv-administered $A \beta$ " rat model using well-characterized $A \beta 1-42$ oligomers.

\section{Materials and Methods}

\subsection{Preparation of A $\beta 1-42$ Peptide Samples and Different Oligomeric Assemblies}

\subsubsection{Preparation of Different A $\beta 1-42$ Oligomeric Assemblies}

The oligomeric $A \beta 1-42$ peptide was synthesized in the following way: the $A \beta$ peptide precursor iso-A $\beta 1-42$ was synthesized by Fmoc-chemistry and transformed at neutral $\mathrm{pH}$ to $\mathrm{A} \beta 1-42$ by $\mathrm{O} \rightarrow \mathrm{N}$ acyl migration in a short period of time, resulting in a water soluble oligomeric mixture of $A \beta 1-42$ oligomers as previously described [74]. Synthetic iso-Abeta peptide was pre-treated with HFIP in order to facilitate its oligomerization, and to standardize its aggregation. The aggregation grade of these oligomers thus formed was standardized. In these studies, the soluble A $\beta 1-42$ oligomeric peptide samples were freshly prepared by incubating the oligomeric $\mathrm{A} \beta 1-42$ peptide on $37^{\circ} \mathrm{C}$ in $\mathrm{PBS}$ at $\mathrm{pH} 7.4$ for different time courses ( $24 \mathrm{~h}$ and $168 \mathrm{~h}$ ) at the concentrations of 25,75 and $200 \mu \mathrm{M}$, respectively. Samples were sonicated in normal bath sonicator for $5 \mathrm{~min}$. Before use, each sample was subsequently diluted to the final concentration of $10 \mu \mathrm{M}$, and $15 \mu \mathrm{L}(2 \times 7.5 \mu \mathrm{L})$ of these solutions were injected into rat brain hemispheres (see Surgery). The amount of $A \beta 1-42$ injected at the concentration of $10 \mu \mathrm{M}$ in each case equaled 50 pmol or $225 \mathrm{ng}$ of $A \beta$ peptides.

The fluorescent labeled $A \beta$ peptide (AMCA-A $\beta$ ) was synthesized also in our research group [76].

\subsubsection{Atomic Force Microscopy Studies (AFM) of A $\beta 1-42$ Assemblies}

For the experiment, $10 \mu \mathrm{L}$ of peptide solution were pipetted onto freshly cleaved mica (Muscovite mica, V-1 quality, Electron Microscopy Sciences, Washington, DC, USA). After 2 min, the samples were washed twice with $10 \mu \mathrm{L}$ of distilled water and then dried with nitrogen gas. The AFM images were obtained using tapping mode on a NT-MDT Solver Scanning Probe Microscope (NT-MDT Spectrum Intruments, Moscow, Russia) under ambient conditions. AFM tips type PPP-NVHAuD-10 manufactured by NANOSENSORS (Neuchâtel, Schwitzerland) were applied with a nominal radius of curvature of $2 \mathrm{~nm}$ and $15 \mu \mathrm{m}$ length. The non-contact silicon cantilevers having typical force constant of $42 \mathrm{~N} / \mathrm{m}$ and resonance frequency of $278.8 \mathrm{kHz}$. Further information of the tip: material $\mathrm{n}^{+}$-silicon, resistivity $0.01-0.02 \Omega \mathrm{cm}$, thickness $4.0 \pm 1 \mu \mathrm{m}$, length: $125 \pm 10 \mu \mathrm{m}$, width $30 \pm 7.5 \mu \mathrm{m}$. 


\subsubsection{Fluorescent Microscopy}

For fluorescent microscopy study, rats $(n=2)$ received fibrillar form, and, in the other experiment, rats $(n=4)$ received oligomeric form and of AMCA (7-Amino-4-methylcoumarin-3-acetic acid)-labeled $\mathrm{A} \beta 1-42$ as a single dose in dilution of AMCA-A $\beta 1-42: A \beta 1-42$ 2:7 ratio (concentrations: AMCA-A $\beta 1-42$ $16.7 \mu \mathrm{M} ; \mathrm{A} \beta 1-42=58.3 \mu \mathrm{M}$ in total of $75 \mu \mathrm{M}$ final peptide concentration). $\mathrm{fA} \beta$ was administered bilaterally (10-10 $\mu \mathrm{L}$ per site), and oA $\beta$ unilaterally into the right cerebroventriculum $(7.5 \mu \mathrm{L}$ pro animal). $60 \mathrm{~min}$ after $\mathrm{fA} \beta 1-42$, and 5 or $60 \mathrm{~min}$ after $\mathrm{oA} \beta 1-42$ administration the rats were transcardially perfused $(100 \mathrm{~mL} \mathrm{PBS}, \mathrm{pH}=7.4)$. The brains were removed and cut to $30 \mu \mathrm{m}$ thick sagittal sections. Sections were placed on glass slides, air dried, and mounted in Gel Mount (Biomeda, San Diego, CA, USA). Fluorescent signal was examined in the sections by a Nikon Eclipse TE2000 fluorescent microscope (Nikon, Tokyo, Japan) and photographed by a Spot RT digital camera (Diagnostic Instruments, Sterling Heights, MI, USA).

\subsection{Treatment Groups}

4.2.1. Studies on Two Different A $\beta 1-42$ Oligomers ( $24 \mathrm{~h}$ and $168 \mathrm{~h}$ Aggregation Time, Concentration $25 \mu \mathrm{M}$ )

Subjects were divided into three groups: the control group $(n=12)$ was injected with hydrocarbonate buffered saline (HCBS) solution, the other two groups were injected with $24 \mathrm{~h}$ aggregated $\mathrm{A} \beta 1-42(n=12)$ and a $168 \mathrm{~h}$ aggregated $\mathrm{A} \beta 1-42(n=12)$.

\subsubsection{Systematic Studies for Finding the Most Toxic Form among Six Different $A \beta 1-42$ Oligomers}

oA $\beta$ samples were prepared in combination of three different A $\beta 1-42$ aggregation concentrations $(25,75$ and $200 \mu \mathrm{M})$ with two different aggregation times ( $24 \mathrm{~h}$ and $168 \mathrm{~h})$. The experiments were divided into two divisions: oA $\beta$ samples of $24 \mathrm{~h}$ and $168 \mathrm{~h}$, respectively (altogether six groups):

A/ A $\beta 1-42,24 \mathrm{~h}$ aggregation time, $\mathrm{c}=25 \mu \mathrm{M}$; mean particle diameter $6.5 \mathrm{~nm}$,

$\mathrm{B} / \mathrm{A} \beta 1-42,24 \mathrm{~h}$ aggregation time, $\mathrm{c}=75 \mu \mathrm{M}$; mean particle diameter $6.5 \mathrm{~nm}$,

C/ A $\beta 1-42,24 \mathrm{~h}$ aggregation time, $\mathrm{c}=200 \mu \mathrm{M}$; mean particle diameter $10.3 \mathrm{~nm}$,

$\mathrm{D} / \mathrm{A} \beta 1-42,168 \mathrm{~h}$ aggregation time, $\mathrm{c}=25 \mu \mathrm{M}$; mean particle diameter $8.2 \mathrm{~nm}$,

$\mathrm{E} / \mathrm{A} \beta 1-42,168 \mathrm{~h}$ aggregation time, $\mathrm{c}=75 \mu \mathrm{M}$; mean particle diameter $8.0 \mathrm{~nm}$,

$\mathrm{F} / \mathrm{A} \beta 1-42,168 \mathrm{~h}$ aggregation time, $\mathrm{c}=200 \mu \mathrm{M}$; mean particle diameter $21.5 \mathrm{~nm}$.

The control groups ( $n=11$ in the $24 \mathrm{~h}$ and $n=12$ in the $168 \mathrm{~h}$ experiments) in both studies were treated with HCBS. For the statistical analysis, the mean of data of the two control groups were evaluated $(n=23)$. Table 1 summarizes the characteristics of $A \beta$-treated groups $(\mathrm{A}-\mathrm{F})$ to simplify further orientation.

\subsubsection{Surgery and Icv Administration of $\mathrm{oA} \beta 1-42$}

Before surgery, rats were deeply anesthetized by e.g., injection of ketamine $(10.0 \mathrm{mg} / 100 \mathrm{~g})$ and xylasine $(0.8 \mathrm{mg} / 100 \mathrm{~g})$ mixture, and were placed in a stereotaxic apparatus. A midline incision of the scalp was made, and the skull was carefully cleared from the skin and the muscles. After that two holes were drilled above the target regions. Every solution was injected icv with Hamilton syringe bilaterally, into each hemisphere. Furthermore, a $7.5 \mu \mathrm{L}$ solution was injected per site $(1.5 \mu \mathrm{L} / \mathrm{min})$. The coordinates were from bregma: AP: $-1.0 ; \mathrm{ML}: \pm 1.5$; DV: -4.5 . [77]. The animals were treated after the surgery with antibiotics and analgesic. 


\subsection{Spatial Navigation of Rats in a Morris Water Maze (MWM)}

\subsubsection{Experimental Animals and Housing}

Adult male Charles River-Harlan rats (Domaszék, Hungary) were the subjects of the experiments, weighing 250-300 g before surgery. After arrival, the animals were housed under constant temperature and lighting conditions $\left(23^{\circ} \mathrm{C}, 12: 12 \mathrm{~h}\right.$ light/dark cycle, lights on at 7:00). The rodents had free access to food and water throughout the experiment. After arrival, the animals were gently handled by daily measuring. Experiments were performed in accordance with the Hungarian Health Committee and the European Communities Council Directive of 24. November 1986 (86/609/EEC). Formal approvals to conduct the experiments have been obtained from the Animal Experimentation Committees of the University of Szeged and of the Biological Research Center, and from the local authorities (XVI/03835/001/2006).

\subsubsection{Morris-Water Maze Experiments}

Animals were trained in open-field water maze (diameter: $180 \mathrm{~cm})$ filled with water $\left(23 \pm 1^{\circ} \mathrm{C}\right)$ that was made opaque with milk. The pool was divided into four virtual quadrants, and the invisible platform (diameter: $10 \mathrm{~cm}$ ) was submerged in the middle of one of the four quadrants. Around the pool, there was a black curtain. The animals were allowed to swim for 5 days, twice a day and launched from four different starting points. They were placed into the water facing the wall of the pool and were given $90 \mathrm{~s}$ to find the platform and $15 \mathrm{~s}$ to stay on it. Animals that did not find the platform were gently guided and placed on it. The escape latency data were calculated automatically by a video tracking system (EthoVision 2002, Noldus Information Technology, Wageningen, The Netherlands). The means of the data (+SEM) from the first swimming sessions were used for statistics.

\subsection{Histology}

After the Morris water maze test, the animals were deeply anesthetized and transcardially perfused with $150 \mathrm{~mL} 4{ }^{\circ} \mathrm{C}$ phosphate-buffered saline solution (PBS), followed by $250 \mathrm{~mL} 4{ }^{\circ} \mathrm{C}$ paraformaldehyde solution ( $4 \%$ in phosphate buffer, $\mathrm{pH} 7.4$ ). The brains were removed and postfixed for $24 \mathrm{~h}$ in the same fixative $\left(4^{\circ} \mathrm{C}\right)$, and subsequently cryoprotected in $30 \%$ sucrose solution for $72 \mathrm{~h}$ $\left(4{ }^{\circ} \mathrm{C}\right)$. Brains were cut on a cryostat to $30 \mu \mathrm{m}$ hippocampal coronal sections, and the slices were collected and stored at $4{ }^{\circ} \mathrm{C}$ in PBS for free floating histochemistry.

\subsubsection{Cresyl Violet (Nissl) Staining}

The cresyl violet staining is used for neuronal tissue, the stain binds to the acidic components of the neuronal cytoplasm, showing the number of viable neurons. Slides were stained into the filtered $1 \%$ cresyl violet solution for $5 \mathrm{~min}$ and dehydrated subsequently in $50 \%, 70 \%, 95 \%$, and twice in $100 \%$ ethanol for $1 \mathrm{~min}$ each. Slides were finally placed in xylene for another $10 \mathrm{~min}$ and coverslipped.

\subsubsection{Tau-Immunohistology}

To visualize the presence of neurofibrillars tangles, we used human PHF-tau Mab (clone AT100) primer antibody at 1:800 dilution in PBS (pH 7.4) for immunostaining.

After quenching of endogenous peroxidase activity and a blocking step, the sections were incubated overnight at $4{ }^{\circ} \mathrm{C}$ with the primary antibody in the presence of $20 \%$ goat serum and Triton X-100 0.2\%. On the following day, the sections were washed in PBS and incubated $1 \mathrm{~h}$ at room temperature with the second biotinylated goat anti-rat antibody (Vector Laboratories, Burlingame, CA, USA, 1:400). The next step was a 1-hour incubation with avidine-biotin complex (Vectastain Elit ABC Kit, Vector Laboratories, Burlingame, CA, USA; 1:400) and detection with nickel-enhanced 3,3'-diaminobenzidine. After immunostaining and washing, all sections were mounted on gelatin-coated slides, air-dried, dehydrated and coverslipped with DPX, a synthetic 
resin mounting media for histology (Fluka BioChemika, Buchs, Switzerland). Digital photographs were taken by a digital slide scanner (Mirax Midi, Carl Zeiss, Hungary); for the analysis, we used the Histoquant program (3DHistech, Budapest, Hungary).

\subsection{Quantification of Dendritic Spine Density Using Golgi Impregnation}

The FD Rapid GolgiStainTM Kit (FD NeuroTecnologies, Consulting \& Services, Inc., San Diego, CA, USA) was used ( $n=6,2-2$ slices per group and 3-3 neurons per slice) for measuring changes of dendritic spine density in the hippocampal CA1 area.

Experimental animals were deeply anesthetized before the brain was removed from the skull. The brains were removed as quickly as possible and handled carefully to avoid damage or pressing of the tissue. The tissue was immersed in the impregnation solution $(\mathrm{A}+\mathrm{B}$ solution) and stored at room temperature for 2 weeks in the dark. The brains were transferred into another solution $(C)$ and stored at $4{ }^{\circ} \mathrm{C}$ in the dark for at least $48 \mathrm{~h}$. In addition, $100 \mu \mathrm{m}$ coronal sections were cut with microtome (Zeiss Microm HM 650 V, Carl Zeiss AG, Oberkochen, Germany). Sections were mounted on gelatin coated glass slides. After the staining procedure and dehydration, the slides were covered with DPX (VWR international).

The Golgi sections were studied by inverse light microscope, using oil-immersion objectives. The spine density of the proximal apical dendrite area was analyzed (100-200 $\mu \mathrm{m}$ from soma). One segment (100 $\mu \mathrm{m}$ in length) from a second-third-order dendrite protruding from its parent apical dendrite was chosen in each examined neuron for spine density quantification, as described by [78]. The dendrites were selected under a $100 \times$ oil immersion lens and the images $(600 \times)$ of these apical dendrites were captured through a CCD camera $(1600 \times 1200$ pixel $)$ connected to a light microscope (Olympus Vanox-T AH-2, Olympus Optical CO, LTD., Tokyo, Japan) and a computer. Serial images were made from each dendrite in the whole of the analyzed segment. The captured multiple photomicrographs from one dendrite were then stacked into one file. To stack the images, the Image- Pro-Plus image analysis software (IPP; Media Cybernetics, Silver Springs, MD, USA) was used. Measurement of the spine density was performed by two independent experimenters to blind the analysis.

\subsection{Ex Vivo Electrophysiological Studies}

\subsubsection{Stimulation Protocols}

Using standard procedures, $350 \mu \mathrm{m}$ thick transverse acute hippocampal slices were prepared from the brain using a McIlwain tissue chopper (Campden Instruments, Loughborough, UK). Slices were incubated in carbogenated standard artificial cerebrospinal fluid (ACSF; $\mathrm{pH} 7.4$ ) at ambient temperature for at least 60 min that contained the followings in $\mathrm{mM}: \mathrm{NaCl}, 130 ; \mathrm{KCl}, 3.5 ; \mathrm{CaCl}_{2}, 2 ; \mathrm{MgCl}_{2}$, 2; $\mathrm{NaH}_{2} \mathrm{PO}_{4}, 0.96 ; \mathrm{NaHCO}_{3}, 24 ; \mathrm{D}$-glucose, 10 . Individual slices were transferred to a 3D-MEA chip with 60 tip-shaped electrodes $(40 \mu \mathrm{m}$ in diameter and $50-70 \mu \mathrm{m}$ in height, spaced by $200 \mu \mathrm{m}$, impedance at $1 \mathrm{kHz}: 250-450 \mathrm{k} \Omega$, noise level: $15-20 \mu \mathrm{V}$; purchased from Ayanda Biosystems, S.A., Lausanne, Switzerland). The surrounding solution was removed quickly and the slice was immobilized by a grid. The slice was continuously perfused with carbogenated standard ACSF $(1.5 \mathrm{~mL} / \mathrm{min}$ at $34{ }^{\circ} \mathrm{C}$ ) during the whole recording session. Data were recorded by a standard, commercially available MEA (multi-electrode array) setup (Multi Channel Systems MCS GmbH, Reutlingen, Germany).

The Schaffer-collateral was stimulated by injecting a biphasic current waveform $( \pm 100 \mu \mathrm{s})$ through one selected electrode at $0.033 \mathrm{~Hz}$, while the rest of them could be used as recording electrodes. The positioning of the stimulating electrodes and that of the regions in the slices, compared to each other, were constantly synchronized during the various investigations. The peak-to-peak amplitudes of field excitatory postsynaptic potentials (fEPSPs) at the stratum radiatum of CA1 were analyzed. After a $30 \mathrm{~min}$ incubation period, the threshold and the maximum of stimulation intensity for evoke responses was determined. For evoking responses, $30 \%$ of the maximal stimulation intensity was used. 
When stable evoked fEPSPs were detected (for at least $20 \mathrm{~min}$ ) LTP was induced, using a theta-burst stimulation (TBS) protocol applied at the maximum stimulation intensity. TBS comprised of 15 trains administered at $5 \mathrm{~Hz}$, the individual trains contained 4 pulses separated by $10 \mathrm{~ms}$. LTP was followed for an hour.

For the statistical analysis of ex vivo recordings, the peak-to-peak amplitude of evoked fEPSPs recorded from the proximal part of stratum radiatum was calculated. The level of LTP was determined comparing the average of fEPSP amplitudes recorded in the last $5 \mathrm{~min}$ of the experiment to the baseline recording.

\subsubsection{Multi-Electrode Array (MEA) Recordings}

Electrophysiological measurements followed the Morris water maze task, in which different icv injected A $\beta 1-42$ was tested. TBS induced LTP recordings were performed using a multi-electrode array (MEA) setup.

After establishing a stable baseline, LTP was elicited by applying a theta-burst stimulation protocol and followed for an hour. The average of the peak-to-peak amplitudes of fEPSPs before the LTP induction was taken as 100\%. The slices obtained from HCBS-injected animals showed robust potentiation after TBS ( $230 \pm 24 \% ; n=15$ channels from 5 slices). There were two more groups of icv injected animals treated with $24 \mathrm{~h}$ and $168 \mathrm{~h}$ A $\beta 1-42$ aggregates. The $24 \mathrm{~h}$ A $\beta 1-42$ assemblies caused a minor impairment in LTP (184 $\pm 7 \% ; n=26$ channels from 6 slices), while the $168 \mathrm{~h}$ amyloid aggregates led to a major disruption of potentiation ( $145 \pm 11 \% ; n=21$ channels from 6 slices).

\subsection{Statistical Analysis}

Statistical analysis of MEA recordings: all data were expressed as the mean \pm SEM. Statistical significance was determined by parametric analysis of one-way ANOVA followed by Fisher's LSD post hoc test for LTP using the statistical software OriginPro 8 package (Origin Lab, Northampton, MA, USA). Differences with a $p$-value of less than $0.05\left(^{*}\right), 0.01\left({ }^{* *}\right)$ and $0.001\left(^{* *}\right)$ were considered significant. Statistical analysis of the Morris water maze experiment (Figures 9 and 10) was performed using SPSS software and Python's Lifelines library (Davidson-Pilon, C., Lifelines, 2016), Github repository. The latency time to attain the platform (with $90 \mathrm{~s}$ limit) was measured in order to decide which of the four groups has the highest learning rate. The longer the latency time to the platform is, the less the rats' capability to learn. "Survival curves" using the Cox Proportional Hazard model were fitted, where the days and the treatments were selected as covariates. The comparison of treatment groups was performed using log-rank tests.

One-way ANOVA followed by Fisher's LSD post hoc test was used for histological analysis, for dendritic spine density measurements and for LTP analysis using SPSS statistical software. Differences with a $p$-value of less than 0.05 were considered significant unless indicated otherwise.

Acknowledgments: We are very grateful for László Siklós for the measurements of dendritic spine density. The authors express their thanks to Anita Kurunczi and Eszter Sipos for the studies on AMCA labeled A $\beta$ fibrils. This work was supported by the EC Health Program "Memoload" (FP-7 project $n^{\circ} 201.159$ ) and the Hungarian NKFIH research grant GINOP-2.3.2-15-2016-00060.

Author Contributions: Ágnes Kasza was responsible for the study plan, icv administration, MWM performance, and Golgi-Cox procedure; Botond Penke took care of the study plan and writing the manuscript; Zsuzsanna Frank was responsible for icv administration, histology and the Golgi-Cox procedure; Zsolt Bozsó handled amyloid synthesis; Viktor Szegedi took care of the study plan and LTP measurements; Ákos Hunya was responsible for MWM and histology statistics, and graphics; Klaudia Németh took care of icv administration; Gábor Kozma handled AFM studies; and Lívia Fülöp was responsible for the study plan, amyloid synthesis, and AFM studies.

Conflicts of Interest: The authors declare no conflict of interest. 


\section{Abbreviations}

$\begin{array}{ll}\text { ACSF } & \text { Artificial cerebrospinal fluid } \\ \text { AD } & \text { Alzheimer's disease } \\ \text { AFM } & \text { Atomic force microscopy } \\ \text { AMCA } & 7 \text { Amino-4-methylcoumarin-3-acetic acid } \\ \text { ANOVA } & \text { Analysis of variance } \\ \text { ApoE } & \text { Apolipoprotein E } \\ \text { APP } & \text { Amyloid precursor protein } \\ \text { A } \beta & \text { Beta-amyloid } \\ \text { CA } & \text { Cornu Ammonis } \\ \text { EOAD } & \text { Early-onset AD } \\ \text { ER } & \text { Endoplasmic reticulum } \\ \text { fA } \beta & \text { Fibrillar form of A } \beta \\ \text { fEPSP } & \text { Field excitatory postsynaptic potential } \\ \text { HC } & \text { Hippocampus } \\ \text { HCBS } & \text { Hydrocarbonate buffered saline } \\ \text { icv } & \text { Intracerebroventricular } \\ \text { LOAD } & \text { Late-onset AD } \\ \text { LTP } & \text { Long term potentiation } \\ \text { MEA } & \text { Multi-electrode array } \\ \text { MWM } & \text { Morris water maze } \\ \text { NFTs } & \text { Neurofibrillary tangles } \\ \text { oA } \beta & \text { Oligomeric form of A } \beta \\ \text { PBS } & \text { Phosphate-buffered saline solution } \\ \text { PCA-AD } & \text { Posterial cortical atrophy variant of AD } \\ \text { PSEN1, } & \text { Presenilin-1 and 2 } \\ \text { r-AD } & \text { Rapidy progressive form of AD } \\ \text { t-AD } & \text { Typical prolonged-duration form of AD } \\ \text { TBS } & \text { Theta-burst stimulation } \\ & \end{array}$

\section{References}

1. Halliday, M.; Mallucci, G.R. Targeting the unfolded protein response in neurodegeneration: A new approach to therapy. Neuropharmacology 2014, 7, 169-174. [CrossRef] [PubMed]

2. Bredesen, D.E.; Rao, R.V.; Mehlen, P. Cell death in the nervous system. Nature 2006, 443, 796-802. [CrossRef] [PubMed]

3. Rubinsztein, D.C. The roles of intracellular protein-degradation pathways in neurodegeneration. Nature 2006, 443, 780-786. [CrossRef] [PubMed]

4. Lam, B.; Masellis, M.; Freedman, M.; Stuss, D.T.; Black, S.E. Clinical, imaging, and pathological heterogeneity of the Alzheimer's disease syndrome. Alzheimers Res. Ther. 2013, 5, 1-14. [CrossRef] [PubMed]

5. Blennow, K.; de Leon, M.J.; Zetterberg, H. Alzheimer's disease. Lancet 2006, 368, 387-403. [CrossRef]

6. Tanzi, R.E. The genetics of Alzheimer disease. Cold Spring Harb. Perspect. Med. 2012, 2. [CrossRef] [PubMed]

7. Piaceri, I.; Nacmias, B.; Sorbi, S. Genetics of familial and sporadic Alzheimer's disease. Front. Biosci. (Elite Ed.) 2013, 5, 167-177. [CrossRef] [PubMed]

8. Bettens, K.; Sleegers, K.; Van Broeckhoven, C. Genetic insights in Alzheimer's disease. Lancet Neurol. 2013, 12, 92-104. [CrossRef]

9. Giri, M.; Zhang, M.; Lu, Y. Genes associated with Alzheimer's disease: An overview and current status. Clin. Interv. Aging 2016, 11, 665-681. [CrossRef] [PubMed]

10. Hardy, J. The amyloid hypothesis for Alzheimer's disease: A critical reappraisal. J. Neurochem. 2009, 110, 1129-1134. [CrossRef] [PubMed]

11. Hardy, J.; Allsop, D. Amyloid deposition as the central event in the etiology of Alzheimers-Disease. Trends Pharmacol. Sci. 1991, 12, 383-388. [CrossRef] 
12. Cavallucci, V.; D'Amelio, M.; Cecconi, F. Abeta toxicity in Alzheimer's disease. Mol. Neurobiol. 2012, 45, 366-378. [CrossRef] [PubMed]

13. Sakono, M.; Zako, T. Amyloid oligomers: Formation and toxicity of A-beta oligomers. FEBS J. 2010, 277, 1348-1358. [CrossRef] [PubMed]

14. Walsh, D.M.; Klyubin, I.; Fadeeva, J.V.; Cullen, W.K.; Anwyl, R.; Wolfe, M.S.; Rowan, M.J.; Selkoe, D.J. Naturally secreted oligomers of amyloid beta protein potently inhibit hippocampal long-term potentiation in vivo. Nature 2002, 416, 535-539. [CrossRef] [PubMed]

15. Upadhaya, A.R.; Capetillo-Zarate, E.; Kosterin, I.; Abramowski, D.; Kumar, S.; Yamaguchi, H.; Walter, J.; Fandrich, M.; Staufenbiel, M.; Thal, D.R. Dispersible amyloid beta-protein oligomers, protofibrils, and fibrils represent diffusible but not soluble aggregates: Their role in neurodegeneration in amyloid precursor protein (APP) transgenic mice. Neurobiol. Aging 2012, 33, 2641-2660. [CrossRef] [PubMed]

16. Hayden, E.Y.; Teplow, D.B. Amyloid beta-protein oligomers and Alzheimer's disease. Alzheimers Res. Ther. 2013, 5, 60-70. [CrossRef] [PubMed]

17. De Felice, F.G.; Munoz, D.P. Opportunities and challenges in developing relevant animal models for Alzheimer's disease. Ageing Res. Rev. 2016, 26, 112-114. [CrossRef] [PubMed]

18. Casadesus, G. Ebook: Handbook of Animal Models in Alzheimer's Disease, 1st ed.; IOS Press: Amsterdam, The Netherlands, 2011; pp. 1-352, ISBN 978-1-60750-733-8.

19. Lecanu, L.; Papadopoulos, V. Modeling Alzheimer's disease with non-transgenic rat models. Alzheimers Res. Ther. 2013, 5. [CrossRef]

20. Sasaguri, H.; Nilsson, P.; Hashimoto, S.; Nagata, K.; Saito, T.; De Strooper, B.; Hardy, J.; Vassar, R.; Winblad, B.; Saido, T.C. App mouse models for Alzheimer's disease preclinical studies. EMBO J. 2017, 36, 2473-2487. [CrossRef] [PubMed]

21. Link, C.D. Expression of human beta-amyloid peptide in transgenic caenorhabditis-elegans. Proc. Natl. Acad. Sci. USA 1995, 92, 9368-9372. [CrossRef] [PubMed]

22. Link, C.D. C-elegans models of age-associated neurodegenerative diseases: Lessons from transgenic worm models of Alzheimer's disease. Exp. Gerontol. 2006, 41, 1007-1013. [CrossRef] [PubMed]

23. Bouleau, S.; Tricoire, H. Drosophila models of Alzheimer's disease: Advances, limits, and perspectives. J. Alzheimers Dis. 2015, 45, 1015-1038. [PubMed]

24. Crowther, D.C.; Kinghorn, K.J.; Miranda, E.; Page, R.; Curry, J.A.; Duthie, F.A.I.; Gubb, D.C.; Lomas, D.A. Intraneuronal a beta, non-amyloid aggregates and neurodegeneration in a Drosophila model of Alzheimer's disease. Neuroscience 2005, 132, 123-135. [CrossRef] [PubMed]

25. Dodart, J.C.; May, P. Overview on rodent models of Alzheimer's disease. Curr. Protoc. Neurosci. 2005. [CrossRef]

26. Gotz, J.; Schonrock, N.; Vissel, B.; Ittner, L.M. Alzheimer's disease selective vulnerability and modeling in transgenic mice. J. Alzheimers Dis. 2009, 18, 243-251. [CrossRef] [PubMed]

27. Puzzo, D.; Lee, L.; Palmeri, A.; Calabrese, G.; Arancio, O. Behavioral assays with mouse models of Alzheimer's disease: Practical considerations and guidelines. Biochem. Pharmacol. 2014, 88, 450-467. [CrossRef] [PubMed]

28. Webster, S.J.; Bachstetter, A.D.; Nelson, P.T.; Schmitt, F.A.; Van Eldik, L.J. Using mice to model Alzheimer's dementia: An overview of the clinical disease and the preclinical behavioral changes in 10 mouse models. Front. Genet. 2014, 5, 88. [CrossRef] [PubMed]

29. Klohs, J.; Rudin, M.; Shimshek, D.R.; Beckmann, N. Imaging of cerebrovascular pathology in animal models of Alzheimer's disease. Front. Aging Neurosci. 2014, 6, 32. [CrossRef] [PubMed]

30. Lindholm, J.S.O.; Castren, E. Mice with altered BDNF signaling as models for mood disorders and antidepressant effects. Front. Behav. Neurosci. 2014, 8, 143. [CrossRef] [PubMed]

31. Onos, K.D.; Rizzo, S.J.S.; Howell, G.R.; Sasnera, M. Toward more predictive genetic mouse models of Alzheimer's disease. Brain Res. Bull. 2016, 122, 1-11. [CrossRef] [PubMed]

32. Orta-Salazar, E.; Vargas-Rodríguez, I.; Castro-Chavira, S.A.; Feria-Velasco, A.I.; Díaz-Cintra, S. Alzheimer's disease: From animal models to the human syndrome. In Update on Dementia; Moretti, D., Ed.; Intech: Rijeka, Croatia, 2016; ISBN 978-953-51-2654-6.

33. Esquerda-Canals, G.; Montoliu-Gaya, L.; Guell-Bosch, J.; Villegas, S. Mouse models of Alzheimer's disease. J. Alzheimers Dis. 2017, 57, 1171-1183. [CrossRef] [PubMed] 
34. Cavanaugh, S.E.; Pippin, J.J.; Barnard, N.D. Animal models of Alzheimer disease: Historical pitfalls and a path forward. ALTEX 2014, 31, 279-302. [CrossRef] [PubMed]

35. Filipcik, P.; Zilka, N.; Bugos, O.; Kucerak, J.; Koson, P.; Novak, P.; Novak, M. First transgenic rat model developing progressive cortical neurofibrillary tangles. Neurobiol. Aging 2012, 33, 1448-1456. [CrossRef] [PubMed]

36. Cohen, R.M.; Rezai-Zadeh, K.; Weitz, T.M.; Rentsendorj, A.; Gate, D.; Spivak, I.; Bholat, Y.; Vasilevko, V.; Glabe, C.G.; Breunig, J.J.; et al. A transgenic Alzheimer rat with plaques, tau pathology, behavioral impairment, oligomeric abeta, and frank neuronal loss. J. Neurosci. 2013, 33, 6245-6256. [CrossRef] [PubMed]

37. Selkoe, D.J. Alzheimer's disease is a synaptic failure. Science 2002, 298, 789-791. [CrossRef] [PubMed]

38. Selkoe, D.J. Soluble oligomers of the amyloid beta-protein impair synaptic plasticity and behavior. Behav. Brain Res. 2008, 192, 106-113. [CrossRef] [PubMed]

39. Shankar, G.M.; Walsh, D.M. Alzheimer's disease: Synaptic dysfunction and A-beta. Mol. Neurodegener. 2009, 4, 48. [CrossRef] [PubMed]

40. Balducci, C.; Beeg, M.; Stravalaci, M.; Bastone, A.; Sclip, A.; Biasini, E.; Tapella, L.; Colombo, L.; Manzoni, C.; Borsello, T.; et al. Synthetic amyloid-beta oligomers impair long-term memory independently of cellular prion protein. Proc. Natl. Acad. Sci. USA 2010, 107, 2295-2300. [CrossRef] [PubMed]

41. Takeda, S.; Sato, N.; Niisato, K.; Takeuchi, D.; Kurinami, H.; Shinohara, M.; Rakugi, H.; Kano, M.; Morishita, R. Validation of a beta 1-40 administration into mouse cerebroventricles as an animal model for Alzheimer disease. Brain Res. 2009, 1280, 137-147. [CrossRef] [PubMed]

42. Townsend, M.; Cleary, J.P.; Mehta, T.; Hofmeister, J.; Lesne, S.; O’Hare, E.; Walsh, D.M.; Selkoe, D.J. Orally available compound prevents deficits in memory caused by the Alzheimer amyloid-beta oligomers. Ann. Neurol. 2006, 60, 668-676. [CrossRef] [PubMed]

43. Zussy, C.; Brureau, A.; Delair, B.; Marchal, S.; Keller, E.; Ixart, G.; Naert, G.; Meunier, J.; Chevallier, N.; Maurice, T.; et al. Time-course and regional analyses of the physiopathological changes induced after cerebral injection of an amyloid beta fragment in rats. Am. J. Pathol. 2011, 179, 315-334. [CrossRef] [PubMed]

44. Kim, H.Y.; Lee, D.K.; Chung, B.R.; Kim, H.V.; Kim, Y. Intracerebroventricular injection of amyloid-beta peptides in normal mice to acutely induce Alzheimer-like cognitive deficits. J. Vis. Exp. 2016. [CrossRef]

45. Tarasoff-Conway, J.M.; Carare, R.O.; Osorio, R.S.; Glodzik, L.; Butler, T.; Fieremans, E.; Axel, L.; Rusinek, H.; Nicholson, C.; Zlokovic, B.V.; et al. Clearance systems in the brain-implications for Alzheimer disease. Nat. Rev. Neurol. 2015, 11, 457-470. [CrossRef] [PubMed]

46. Jacob, H.J.; Kwitek, A.E. Rat genetics: Attaching physiology and pharmacology to the genome. Nat. Rev. Genet. 2002, 3, 33-42. [CrossRef] [PubMed]

47. Bagheri, M.; Joghataei, M.T.; Mohseni, S.; Roghani, M. Genistein ameliorates learning and memory deficits in amyloid beta((1-40)) rat model of Alzheimer's disease. Neurobiol. Learn. Mem. 2011, 95, 270-276. [CrossRef] [PubMed]

48. Christensen, D.Z.; Bayer, T.A.; Wirths, O. Formic acid is essential for immunohistochemical detection of aggregated intraneuronal a beta peptides in mouse models of Alzheimer's disease. Brain Res. 2009, 1301, 116-125. [CrossRef] [PubMed]

49. He, F.Q.; Qiu, B.Y.; Zhang, X.H.; Li, T.K.; Xie, Q.; Cui, D.J.; Huang, X.L.; Gan, H.T. Tetrandrine attenuates spatial memory impairment and hippocampal neuroinflammation via inhibiting NF-kappaB activation in a rat model of Alzheimer's disease induced by amyloid-beta(1-42). Brain Res. 2011, 1384, 89-96. [CrossRef] [PubMed]

50. O’Hare, E.; Weldon, D.T.; Mantyh, P.W.; Ghilardi, J.R.; Finke, M.P.; Kuskowski, M.A.; Maggio, J.E.; Shephard, R.A.; Cleary, J. Delayed behavioral effects following intrahippocampal injection of aggregated a beta(1-42). Brain Res. 1999, 815, 1-10. [CrossRef]

51. Hong, S.; Beja-Glasser, V.F.; Nfonoyim, B.M.; Frouin, A.; Li, S.M.; Ramakrishnan, S.; Merry, K.M.; Shi, Q.Q.; Rosenthal, A.; Barres, B.A.; et al. Complement and microglia mediate early synapse loss in Alzheimer mouse models. Science 2016, 352, 712-716. [CrossRef] [PubMed]

52. Zhu, D.; Yang, N.; Liu, Y.Y.; Zheng, J.; Ji, C.; Zuo, P.P. M2 macrophage transplantation ameliorates cognitive dysfunction in amyloid-beta-treated rats through regulation of microglial polarization. J. Alzheimers Dis. 2016, 52, 483-495. [CrossRef] [PubMed] 
53. Sipos, E.; Kurunczi, A.; Andras, F.; Penke, Z.; Fulop, L.; Kasza, A.; Janos, H.; Sandor, H.; Veszelka, S.; Balogh, G.; et al. Intranasal delivery of human beta-amyloid peptide in rats: Effective brain targeting. Cell. Mol. Neurobiol. 2010, 30, 405-413. [CrossRef] [PubMed]

54. Sipos, E.; Kurunczi, A.; Kasza, A.; Horvath, J.; Felszeghy, K.; Laroche, S.; Toldi, J.; Parducz, A.; Penke, B.; Penke, Z. Beta-amyloid pathology in the entorhinal cortex of rats induces memory deficits: Implications for Alzheimer's disease. Neuroscience 2007, 147, 28-36. [CrossRef] [PubMed]

55. Kumar, A.; Aggarwal, A.; Singh, A.; Naidu, P.S. Animal models in drug discovery of Alzheimer's disease: A mini review. EC Pharmacol. Toxicol. 2016, 2, 60-79.

56. Salari, S.; Bagheri, M. A review of animal models of Alzheimer's disease: A brief insight into pharmacologic and genetic models. Physiol. Pharmacol. 2016, 20, 5-11.

57. Ruggeri, F.S.; Habchi, J.; Cerreta, A.; Dietler, G. AFM-based single molecule techniques: Unraveling the amyloid pathogenic species. Curr. Pharm. Des. 2016, 22, 3950-3970. [CrossRef] [PubMed]

58. Iliff, J.J.; Wang, M.H.; Liao, Y.H.; Plogg, B.A.; Peng, W.G.; Gundersen, G.A.; Benveniste, H.; Vates, G.E.; Deane, R.; Goldman, S.A.; et al. A paravascular pathway facilitates csf flow through the brain parenchyma and the clearance of interstitial solutes, including amyloid beta. Sci. Transl. Med. 2012, 4, 147ra111. [CrossRef] [PubMed]

59. Mendez-Lopez, M.; Mendez, M.; Sampedro-Piquero, P.; Arias, J.L. Spatial learning-related changes in metabolic activity of limbic structures at different posttask delays. J. Neurosci. Res. 2013, 91, 151-159. [CrossRef] [PubMed]

60. Morris, R. Developments of a water-maze procedure for studying spatial-learning in the rat. J. Neurosci. Methods 1984, 11, 47-60. [CrossRef]

61. Morris, R.G.M.; Anderson, E.; Lynch, G.S.; Baudry, M. Selective impairment of learning and blockade of long-term potentiation by an N-methyl-D-aspartate receptor antagonist, AP5. Nature 1986, 319, 774-776. [CrossRef] [PubMed]

62. Morris, R.G.M.; Garrud, P.; Rawlins, J.N.P.; Okeefe, J. Place navigation impaired in rats with hippocampal-lesions. Nature 1982, 297, 681-683. [CrossRef] [PubMed]

63. Vorhees, C.V.; Williams, M.T. Morris water maze: Procedures for assessing spatial and related forms of learning and memory. Nat. Protoc. 2006, 1, 848-858. [CrossRef] [PubMed]

64. Qiang, W.; Yau, W.M.; Lu, J.X.; Collinge, J.; Tycko, R. Structural variation in amyloid-beta fibrils from Alzheimer's disease clinical subtypes. Nature 2017, 541, 217-221. [CrossRef] [PubMed]

65. Wei, W.; Nguyen, L.N.; Kessels, H.W.; Hagiwara, H.; Sisodia, S.; Malinow, R. Amyloid beta from axons and dendrites reduces local spine number and plasticity. Nat. Neurosci. 2010, 13, 190-196. [CrossRef] [PubMed]

66. Lacor, P.N.; Buniel, M.C.; Chang, L.; Fernandez, S.J.; Gong, Y.S.; Viola, K.L.; Lambert, M.P.; Velasco, P.T.; Bigio, E.H.; Finch, C.E.; et al. Synaptic targeting by Alzheimer's-related amyloid beta oligomers. J. Neurosci. 2004, 24, 10191-10200. [CrossRef] [PubMed]

67. Lacor, P.N.; Buniel, M.C.; Furlow, P.W.; Clemente, A.S.; Velasco, P.T.; Wood, M.; Viola, K.L.; Klein, W.L. A beta oligomer-induced aberrations in synapse composition, shape, and density provide a molecular basis for loss of connectivity in Alzheimer's disease. J. Neurosci. 2007, 27, 796-807. [CrossRef] [PubMed]

68. Chacon, M.A.; Barria, M.I.; Soto, C.; Inestrosa, N.C. Beta-sheet breaker peptide prevents a beta-induced spatial memory impairments with partial reduction of amyloid deposits. Mol. Psychiatry 2004, 9, 953-961. [CrossRef] [PubMed]

69. Borbely, E.; Horvath, J.; Furdan, S.; Bozso, Z.; Penke, B.; Fulop, L. Simultaneous changes of spatial memory and spine density after intrahippocampal administration of fibrillar A $\beta(1-42)$ to the rat brain. Biomed. Res. Int. 2014, 2014, 345305. [CrossRef] [PubMed]

70. Sandberg, A.; Luheshi, L.M.; Sollvander, S.; de Barros, T.P.; Macao, B.; Knowles, T.P.J.; Biverstal, H.; Lendel, C.; Ekholm-Petterson, F.; Dubnovitsky, A.; et al. Stabilization of neurotoxic Alzheimer amyloid-beta oligomers by protein engineering. Proc. Natl. Acad. Sci. USA 2010, 107, 15595-15600. [CrossRef] [PubMed]

71. Fonseca, A.C.; Oliveira, C.R.; Pereira, C.F.; Cardoso, S.M. Loss of proteostasis induced by amyloid beta peptide in brain endothelial cells. Biochim. Biophys. Acta 2014, 1843, 1150-1161. [CrossRef] [PubMed]

72. Kopniczky, Z.; Dochnal, R.; Macsai, M.; Pal, A.; Kiss, G.; Mihaly, A.; Szabo, G. Alterations of behavior and spatial learning after unilateral entorhinal ablation of rats. Life Sci. 2006, 78, 2683-2688. [CrossRef] [PubMed]

73. Avraamides, M.N.; Kelly, J.W. Multiple systems of spatial memory and action. Cogn. Process. 2008, 9, 93-106. [CrossRef] [PubMed] 
74. Bozso, Z.; Penke, B.; Simon, D.; Laczko, I.; Juhasz, G.; Szegedi, V.; Kasza, A.; Soos, K.; Hetenyi, A.; Weber, E.; et al. Controlled in situ preparation of a beta(1-42) oligomers from the isopeptide "iso-a beta(1-42)", physicochemical and biological characterization. Peptides 2010, 31, 248-256. [CrossRef] [PubMed]

75. Lavenex, P.; Amaral, D.G. Hippocampal-neocortical interaction: A hierarchy of associativity. Hippocampus 2000, 10, 420-430. [CrossRef]

76. Fulop, L.; Penke, B.; Zarandi, M. Synthesis and fluorescent labeling of beta-amyloid peptides. J. Pept. Sci. 2001, 7, 397-401. [CrossRef] [PubMed]

77. Paxinos, G.; Watson, C. The Rat Brain in Stereotaxic Coordinates, 6th ed.; Academic Press: London, UK; Sydney, Australia, 2006; pp. 1-456, ISBN 0080475159.

78. Nagy, D.; Kocsis, K.; Fuzik, J.; Marosi, M.; Kis, Z.; Teichberg, V.I.; Toldi, J.; Farkas, T. Kainate postconditioning restores LTP in ischemic hippocampal ca1: Onset-dependent second pathophysiological stress. Neuropharmacology 2011, 61, 1026-1032. [CrossRef] [PubMed]

Sample Availability: Samples of the compounds iso-A $\beta(1-42)$ and $A \beta(1-42)$ are available from the authors. 